Article

\title{
Effects of Hydraulic Loading Rate on Spatial and Temporal Water Quality Characteristics and Crop Growth and Yield in Aquaponic Systems
}

\author{
Teng Yang and Hye-Ji Kim *D \\ Department of Horticulture and Landscape Architecture, Purdue University, \\ West Lafayette, IN 47907-2010, USA; yang1048@purdue.edu \\ * Correspondence: hjikim@purdue.edu
}

Received: 30 November 2019; Accepted: 16 January 2020; Published: 2 February 2020

check for updates

\begin{abstract}
Aquaponics is a rapidly growing food-production system integrating aquaculture and hydroponic crop production through an energy-intensive water recirculation process. Crop performance and yield in aquaponics are affected by essential and toxic nutrient levels in the root zone, which can be regulated by water flow rate. This study was conducted to examine the effects of hydraulic loading rate (HLR) on water quality and crop growth and yield in recirculating aquaponic systems set at three different loading rates: high $\left(3.3 \mathrm{~m}^{3} / \mathrm{m}^{2} /\right.$ day; HFR, which is 12 times lower than recommended loading rate), medium $\left(2.2 \mathrm{~m}^{3} / \mathrm{m}^{2} /\right.$ day; MFR), and low $\left(1.1 \mathrm{~m}^{3} / \mathrm{m}^{2} /\right.$ day; LFR). Crop species varying in growth rate were examined for their optimal HLR: fast-growing Chinese cabbage (Brassica rapa) and lettuce (Lactuca sativa); medium-growing mustard (Brassica juncea) and chia (Salvia hispanica); and slow-growing basil (Ocimum basilicum) and Swiss chard (Beta vulgaris). Compared to LFR, HFR decreased water and leaf temperatures and total ammonium nitrogen (TAN) but increased dissolved oxygen and $\mathrm{pH}$ in aquaponic solution up to one and two weeks after transplant, respectively. HFR increased $\mathrm{NO}_{3}-\mathrm{N}$ concentration by 50 and $80 \%$, respectively, compared to MFR and LFR, while reducing the exposure duration of roots to ammonia $\left(\mathrm{NH}_{3}-\mathrm{N}\right)$ and its peak concentration through rapid dissipation of the toxic compound. Lower electrical conductivity (EC) in HFR during the last two weeks of production was associated with higher plant nutrient uptake and greater biomass production. The leaf greenness, photosynthetic rate $(P n)$, and total plant $\mathrm{N}$ were significantly higher at HFR than LFR. Fish growth rate, fresh weight, and feed-conversion efficiency were also increased by HFR. The growth of fast-growing crops including total fresh weight, shoot fresh weight, leaf area, and $P n$ was not different between HFR and MFR, while HLR had less significant effects on the growth and performance (i.e., shoot fresh weight and whole plant photosynthesis) of slow-growing crops. In conclusion, the flow rate is an important component in aquaponic crop production as it affects spatial and temporal water characteristics and subsequently determines the growth and yield of the crops. HLR at $3.3 \mathrm{~m}^{3} / \mathrm{m}^{2} /$ day was sufficient across the crops allowing better chemical and physical properties of the aquaponic solution for maximum yield and quality. HLR should be maintained at least at $2.2 \mathrm{~m}^{3} / \mathrm{m}^{2} /$ day for the production of fast-growing crops but can be lowered for slow-growing crops.
\end{abstract}

Keywords: nutrient flow; deep water culture; hydroponics; wastewater management; hydraulic retention time; nitrogen; phosphorus; energy use efficiency

\section{Introduction}

With rapid population growth and increasing scarcity of prime cropland, water, and fossil-fuel energy, providing sustainable solutions for food production has become a major challenge. There is 
a strong need for highly productive and sustainable food-production systems that maximize water and nutrient reuse and reduce impact on the environment, especially in areas where water resources are limited [1]. Aquaponics integrates hydroponics with aquaculture [2] and holds great promise for helping to ameliorate the challenges associated with crop production through efficient use of resources. Fish feed is the primary source of nutrients in aquaponics. Ammonia as a waste product excreted by fish exists in two forms, toxic (un-ionized) ammonia $\left(\mathrm{NH}_{3}-\mathrm{N}\right.$ ) and nontoxic (ionized) ammonium ion $\left(\mathrm{NH}_{4}-\mathrm{N}\right)$, and the sum of these two forms is called total ammonia nitrogen (TAN) [3]. Nitrifying bacteria in aquaponic systems oxidize ammonium $\left(\mathrm{NH}_{4}-\mathrm{N}\right)$ to nitrite $\left(\mathrm{NO}_{2}-\mathrm{N}\right)$ and further convert it into nitrate $\left(\mathrm{NO}_{3}-\mathrm{N}\right)$, a nutrient essential for plant growth, by biofilter microorganisms [4]. Plant uptake of $\mathrm{NO}_{3}-\mathrm{N}$ allows reclaimed water to flow back to the fish tank.

With increasing popularity in recent years, recirculating aquaponic systems (RAS) are considered an important driver for the development of integrated food-production systems. According to one recent study, about $74 \%$ of aquaponic systems are indoor-based, recirculating systems where water is continuously recycled through an interconnected series of fish tanks and tanks supporting hydroponic plant crop production [5]. More than $83 \%$ of aquaponic systems are small-scale systems that contain hydroponic units with a fish tank size of about $1000 \mathrm{~L}$ and growing space of about $3 \mathrm{~m}^{2}$ [6]. Small-scale aquaponic systems are typically characterized by higher water-use efficiency but lower electrical-use efficiency [5,7]; and therefore, a well-managed aquaponics will not only reduce water usage and waste discharge to the environment but also improve nutrient retention efficiency and energy efficiency.

Water flow rate is considered one of the key operating parameters in water-based systems including aquaponics, as it affects influent and effluent characteristics, and therefore determines flux of nutrients to the root zone. High flow rates allow faster transport of water and nutrients to the root zone in growing media [8], hydroponics [9], aquaculture wastewater [10], and municipal wastewater treatment $[8,9,11,12]$. For example, when nutrient film technique (NFT) was used as a delivery system of hydroponic solution, water flow rate within the ranges of 1 to $1.5 \mathrm{~L} / \mathrm{min}$ accommodated water and nutrient demand of crops and increased dry mass of lettuce [13] and tomato seedlings [14] by 20\% and $24 \%$, respectively, compared to the higher or lower flow rate counterpart. Meanwhile, flow rates recommended for deep water culture (DWC) hydroponic systems are in the ranges of 2 to $3 \mathrm{~L} / \mathrm{min}$ [15]. Studies on water flow rate optimization in DWC have been limited due to more research focus on its highly dependent dissolved oxygen [16,17]. Oxygen is generally considered as the limiting factor for better crop yield in DWC because plant roots are submerged in water without porous substrates containing air and solid phases.

High water flow rate (HFR, L/day) can be translated into high hydraulic loading rates (HLR, $\mathrm{m}^{3} / \mathrm{m}^{2} /$ day or $\mathrm{m} /$ day; flow rate/total surface area) or low hydraulic retention time (HRT, h; (surface area $\times$ water depth)/flow rate), although these terms are often used in a similar context. A wide range of HLRs from 0.46 to $1.95 \mathrm{~m}^{3} / \mathrm{m}^{2} /$ day have been used successfully to treat aquaculture wastewater using constructed wetlands [10], where $\mathrm{NO}_{3}-\mathrm{N}$ removal efficiency was reduced at HLR as low as $0.63 \mathrm{~m}^{3} / \mathrm{m}^{2} /$ day $[18,19]$. However, it remains in question if such low HLR has a similar effect on the removal efficiency in aquaponic systems.

In contrast, high HLR or low HRT (less than $0.5 \mathrm{~h}$; HLR: $47.8 \mathrm{~m}^{3} / \mathrm{m}^{2} /$ day) has been adopted in conventional aquaponic systems for better fish and plant growth $[6,20]$. Water flow has a direct impact on DO and the accumulation of wastes in the fish tank [6] including harmful N species [21], and therefore, a HRT as high as $0.5 \mathrm{~h}$ (HLR: $38.4 \mathrm{~m}^{3} / \mathrm{m}^{2} /$ day) was recommended in small-scale densely-stocked aquaponic systems (e.g., $>15 \mathrm{~kg}$ fish $/ \mathrm{m}^{3}$ ) to ensure the optimal performance of organisms involved, which can be increased to $1.0 \mathrm{~h} \mathrm{HRT} \mathrm{(HLR:} 19.2 \mathrm{~m}^{3} / \mathrm{m}^{2} /$ day) in aquaponic systems with low stocking densities (e.g., 1-5 kg fish/ $\mathrm{m}^{3}$ ) [6]. However, such high flow rate is energy-intensive and may not be necessary as long as the water environment is favorable for nitrification and crop growth. Such high flow rate may improve water quality by rapidly removing harmful compounds but may reduce the contact time of plant roots with beneficial nutrients. In order to enhance crop growth 
and yield and minimize pumping requirements, the optimal water flow rate of an aquaponic system should be determined.

Meanwhile, the choice of plant species is considered one of the key operational components that can influence the performance of aquaponic systems. For example, plant growth and yield in aquaponic systems may interact with not only the external conditions (i.e., water quality parameters and nutrient availability) but also internal factors such as plant growth rate. Therefore, the differences in plant growth rate may justify different flow rates to optimize crop production in a water-based system.

The main objectives of the study were: (1) to examine the effects of HLR on water quality in aquaponic systems; (2) to investigate the effects of HLR on the growth and performance of crops varying in growth rate; and (3) to determine the optimal HLR for efficient aquaponic system for maximum crop yield.

\section{Materials and Methods}

\subsection{System Design and Flow-Rate Treatment}

This study was conducted in the greenhouse at Purdue University at West Lafayette, IN (lat. $40^{\circ} \mathrm{N}$, long. $86^{\circ} \mathrm{W}$ ) using six aquaponic systems. Prior to the study, the systems were operated for two months with fish and water in a recirculating system, allowing the biofilter (with microbes) to mature and the nutrient levels to increase for plants. Each aquaponic system was equipped with a fish tank $(370 \mathrm{~L})$, a clarifier $(20 \mathrm{~L})$, two stage biofilter (up-flow and down-flow; total volume $=40 \mathrm{~L})[1,22]$ filled with bio-filter media (Kaldnes K1 Media, Aquatic Eco-System, Apopka, FL, USA) yielding a surface area of approximately $30 \mathrm{~m}^{2}$, and a deep-water hydroponic-culture unit (370 L; $\left.1.0 \mathrm{~m}^{2}\right)$ (Figure 1). A peristaltic pump (Masterflex, Cole-Parmer, Vernon Hills, IL, USA) was used to recirculate the aquaponic solution within the system. The total water volume in each aquaponic system was $800 \mathrm{~L}$, and the hydraulic loading rates (HLR) were set at 3.3, 2.2, and $1.1 \mathrm{~m}^{3} / \mathrm{m}^{2} /$ day, respectively, for high(HFR), medium- (MFR), and low- (LFR) flow rate treatments, giving a water-retention time of 6, 9, and $17 \mathrm{~h}$, respectively (Table 1 ). These HLRs were 12 to 35 times lower than the recommended rates by FAO (0.5 HRT) [6] and were chosen based on the flow rates recommended for DWC hydroponic systems (2 to $3 \mathrm{~L} / \mathrm{min}$ ) [15]. Water in the clarifier captured the majority of suspended solids from the fish tank. After passing through the clarifier, the output solution flowed into the biofilter and then the hydroponic culture unit, where DWC was employed. Plants were supported by a foam board set on the top edges of the hydroponic unit. Each of the hydroponic culture units and fish tanks had three air stones to maintain dissolved oxygen (DO) concentrations to nearly full saturation. The fish tanks were covered with a plastic board to prevent algal growth. There was also a lid on each board that remained open to permit light go through plastic tanks during the daytime. Nutrients dissolved in the aquaponic solution were absorbed by plants in the hydroponic culture unit, and the reclaimed water was then recirculated into the fish tank. The water was recirculated continuously within the system and water was not discharged during the study period except for replenishing evapotranspiration losses using reverse-osmosis (RO) water. The photoperiod was $14 \mathrm{~h}$ consisting of natural daylight with supplemental lighting using high-pressure sodium (HPS) lamps. Day (8:00 a.m. to 10:00 p.m.) and night (10:00 p.m. to 8:00 a.m.) air temperatures were set at 24 and $18{ }^{\circ} \mathrm{C}$, respectively. Supplemental photosynthetic photon flux density (PPFD) in the greenhouse was measured at night using a quantum sensor (LI-250A light meter; LI-COR Biosciences, Lincoln, NE, USA). The average daily light integral (DLI) for both solar and supplemental lighting, temperature, and vapor-pressure deficit (VPD) were $20.3 \mathrm{~mol} / \mathrm{m}^{2} / \mathrm{d}, 23.7^{\circ} \mathrm{C}$, and $0.18 \mathrm{kPa}$, respectively, during the study period. 


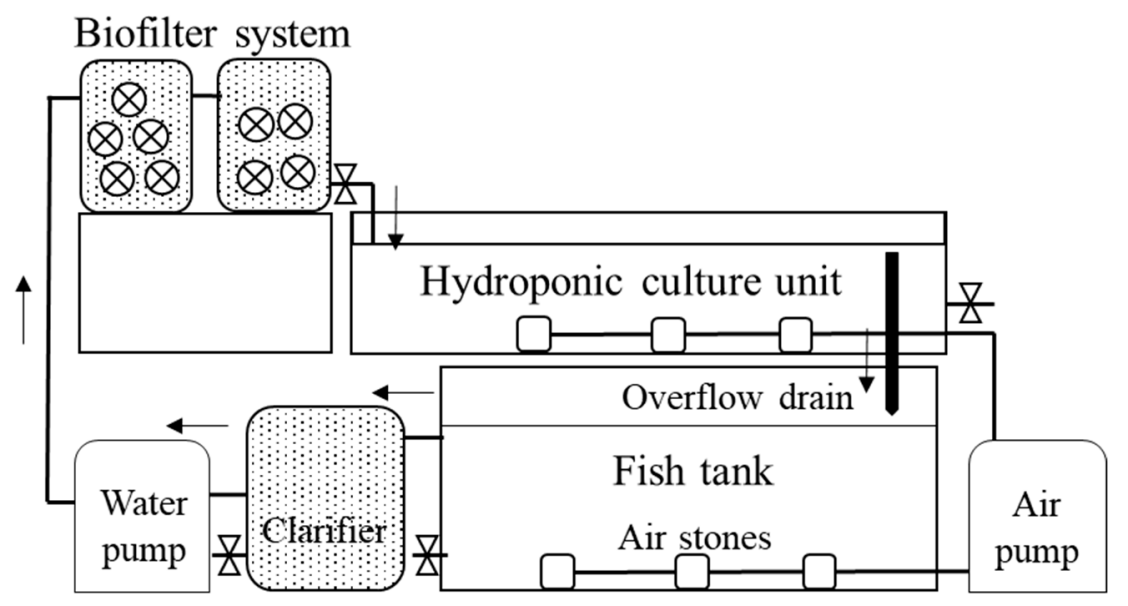

Figure 1. Schematic diagram of the experimental aquaponic system adapted from Yang and Kim (2019).

Table 1. Flow-rate treatments, high (HFR, $3.3 \mathrm{~m} /$ day), medium (MFR, $2.2 \mathrm{~m} /$ day), and low (LFR, $1.1 \mathrm{~m} /$ day) flow rate, set up for deep water culture (DWC) recirculating aquaponic systems.

\begin{tabular}{|c|c|c|c|c|c|}
\hline Treatment & $\begin{array}{c}\text { Flow Rate }{ }^{z} \\
\text { (L/min) }\end{array}$ & $\begin{array}{c}\text { Flow Rate } \\
\text { (L/h) }\end{array}$ & $\begin{array}{c}\text { Flow Rate } \\
\text { (L/day) }\end{array}$ & $\begin{array}{c}\text { HLR } \\
\left(\mathrm{m}^{3} / \mathrm{m}^{2} / \text { day }\right)\end{array}$ & $\begin{array}{c}\text { HRT }^{\mathrm{x}} \text { for DWC } \\
\text { System (h) }\end{array}$ \\
\hline HFR & 2.30 & 138 & 3312 & 3.3 & 5.8 \\
\hline MFR & 1.53 & 92 & 2203 & 2.2 & 8.7 \\
\hline LFR & 0.77 & 46 & 1109 & 1.1 & 17.3 \\
\hline \multicolumn{6}{|c|}{ Recommended flow rate } \\
\hline Aquaponics ${ }^{\mathrm{w}}$ & 26.7 & 1600 & 38400 & 38.4 & 0.5 \\
\hline Hydroponics ${ }^{\mathrm{v}}$ & $2-3$ & $120-180$ & $2880-4320$ & $2.9-4.3$ & $4.4-6.7$ \\
\hline
\end{tabular}

${ }^{\mathrm{z}}$ Flow rate of the aquaponic recirculating system. ${ }^{\mathrm{y}}$ Hydraulic loading rate: Flow rate divided by total surface area of the hydroponic culture unit. ${ }^{x}$ Hydraulic retention time: [(surface area $\times$ water depth)/flow rate]. ${ }^{\mathrm{w}}$ Recommended flow rates for deep-water culture aquaponic systems used in this study. The calculations were made based on the HRT recommended by Somerville et al. (2014) [6]. ${ }^{v}$ Recommended flow rates for hydroponics. The calculations were made based on the flow rate for deep-water culture recommended by Resh (2013) [15].

\subsection{Plant and Fish Materials}

Nile tilapia (Oreochromis niloticus) were obtained from Animal Sciences Research and Education Center at Purdue University, which had been cultivated in a conventional aquaculture system for 4 months prior to the start of the experiment. In each aquaponic system, the fish tank was stocked with a total weight of $7.4 \mathrm{~kg}$ fish (stocking density $=20 \mathrm{~kg} / \mathrm{m}^{3}$ ) and individual fish weight averaged $284 \mathrm{~g}$. Fish feed used in our study was a complete diet containing $41 \%$ protein and $1.1 \%$ phosphorus (AquaMax Sport Fish 500, Purina Mills, St. Louis, MO, USA) with 4.8-mm floating pellets. Fish were fed once per day at 9:00 a.m. with feed at an average rate of $0.5 \%$ body weight. Aquarium thermostatic heaters (Eheim Jager TruTemp ${ }^{\circledR}$, Eheim GmbH \& Co, Deizisau, Germany) were used to maintain water temperature of the fish tanks within optimum range $\left(27-29{ }^{\circ} \mathrm{C}\right)$ for tropical tilapia culture in aquaponic systems.

Six different plant species were cultured in this study, including Chinese cabbage (Brassica rapa cv. Tokyo Bekana), lettuce (Lactuca sativa cv. Cherokee), mustard green (Brassica juncea cv. Golden Frill), chia (Salvia hispanica cv. Red Garnet Microgreens), basil (Ocimum basilicum cv. Genovese), and Swiss chard (Beta vulgaris cv. Rhubarb Chard). Seeds were purchased from a commercial source (Johnny's Selected Seeds, Winslow, ME, USA) and sown in agrifoam (Syndicate Sales, Inc., Kokomo, IN, USA) trays with intervals of few days to standardize seedling size at the time of transplanting (Table S1). Seeds were initially imbibed with tap water, followed by a half-strength fertilizer solution once germinated, and full-strength fertilizer after seedlings developed true leaves [23]. The seedlings were irrigated as necessary with a combination of two water-soluble fertilizers (3:1 mixture of $15 \mathrm{~N}-2.2 \mathrm{P}-12.5 \mathrm{~K}$ Cal-Mag Special and 21N-2.2P-16.6K Multi-Purpose fertilizers, respectively; Everris NA, Dublin, 
$\mathrm{OH}, \mathrm{USA})$. The fertilizer consisted of (mg/L): 150 nitrogen $(\mathrm{N}), 20$ phosphorous $(\mathrm{P}), 122$ potassium $(\mathrm{K})$, 38 calcium $(\mathrm{Ca}), 15$ magnesium $(\mathrm{Mg}), 0.8$ iron $(\mathrm{Fe}), 0.4$ manganese $(\mathrm{Mn})$ and zinc $(\mathrm{Zn}), 0.2$ copper $(\mathrm{Cu})$ and boron (B), and 0.1 molybdenum (Mo). Nitrate form was $76 \%$ of nitrogen provided. The $\mathrm{pH}$ for the fertilizer solution was 5.5-6.0. After the third true leaf emerged, uniform, healthy seedlings were randomly chosen and transplanted into mesh pots, each containing $85 \mathrm{~g}$ clay balls, then transferred to the hydroponic culture unit of aquaponic systems.

\subsection{Plant and Fish Growth Measurements}

Crop growth parameters were measured before transplanting and in the fourth week after transplanting; these included plant height $(\mathrm{cm})$, leaf number, and leaf length $(\mathrm{cm})$. Leaf temperature $\left({ }^{\circ} \mathrm{C}\right)$ was measured at the third week after transplanting using an infrared radiometer (MI-210, Apogee Instruments, Inc., Logan, UT, USA) at approximately $4.8 \mathrm{~cm}$ away from the leaf surface. The average level of chlorophyll content from each young, fully expanded leaf of the canopy was recorded by taking SPAD (soil plant analysis development) readings with a SPAD-502 Chlorophyll meter (Minolta Camera Co. Ltd., Japan). Five readings per leaf were taken and averaged.

The fresh weight of plants was measured non-destructively at the beginning, during, and the end of the study. Plant growth rate was calculated by the weight difference divided by the number of days elapsed between the two measurements. At harvest, plant samples were separated into different tissues (roots, stems, leaves), and immediately weighed for fresh weight and all leaf samples were scanned for leaf area using a LI-3100 leaf area meter (LI-COR, Lincoln, NE, USA). Harvested samples were oven-dried (over $72 \mathrm{~h}$ at $70{ }^{\circ} \mathrm{C}$ ) until a constant weight was measured for dry weight. Specific leaf area (SLA) was calculated by the ratio of leaf area to leaf dry mass.

At the beginning and end of the study, five fish were randomly selected from each fish tank and weighed to get a five-fish weight, then an individual average fish weight was calculated by dividing total weight by the number of fish; this procedure was repeated five times to obtain an average individual fish weight for each aquaponic system. Fish biomass gain was obtained by calculating the difference between initial and final fish weight over the study time (30 days). Feed conversion ratio (FCR), a measure of feed-conversion efficiency, was calculated by dividing the total amount of feed by the fish biomass gain during the experiment. The specific growth rate (SGR), as expressed as the percentage of fish biomass increase per day, was also calculated by dividing the logarithmic form of total fish biomass gain by the number of days of the experiment.

\subsection{Water-Parameters Measurement}

The amount of fish feed $(\mathrm{g})$ and water-quality parameters, such as temperature $\left(\mathrm{T} ;{ }^{\circ} \mathrm{C}\right), \mathrm{pH}$, electrical conductivity (EC; $\mathrm{dS} / \mathrm{m})$, and $\mathrm{DO}(\mathrm{mg} / \mathrm{L})$ at the fish tank and hydroponic culture unit were measured daily before feeding at 9:00 a.m. using the HQ40d portable water quality lab package (HACH Corp., Loveland, CO, USA). A mixture of potassium hydroxide $(2 \mathrm{~N})$ and saturated $(0.05 \mathrm{~N})$ calcium hydroxide ( $\mathrm{v}: \mathrm{v}=1: 1)$ was directly added to the fish tank to adjust $\mathrm{pH}$ to around 7 , daily.

Water samples were obtained from fish tank and hydroponic culture units every 3 days before feeding and were analyzed immediately for TAN, $\mathrm{NO}_{2}-\mathrm{N}, \mathrm{NO}_{3}-\mathrm{N}$ and $\mathrm{PO}_{4}-\mathrm{P}$ concentrations, using HACH reaction kits (Loveland, Co. Ltd., USA), namely Ammonia Reagent Powder Pillows, Nitrite Reagent Powder Pillows, Nitrate Reagent Powder Pillows and Phosphate Reagent Powder Pillows, respectively. Weekly water samples obtained from fish tanks were used to analyze anions (i.e., $\mathrm{NO}_{3}-\mathrm{N}, \mathrm{NO}_{2}-\mathrm{N}, \mathrm{PO}_{4}-\mathrm{P}, \mathrm{SO}_{4}-\mathrm{S}$ ) using ion chromatography (Dionex ICS-5000, Thermo scientific, Co. Ltd., USA) as described in Section 2.7.

Immediately upon the completion of plant production trials, a separate study was conducted in the absence of plants to monitor $\mathrm{NH}_{3}-\mathrm{N}$ and $\mathrm{NO}_{3}-\mathrm{N}$ concentrations in situ for $24 \mathrm{~h}$ using TruLab pH/ISE 1320P meter (YSI, Inc., Yellow Springs, OH, USA) in the hydroponic tank of aquaponic systems. The pH was manually monitored from 9:00 am-9:00 p.m. hourly every day by using the HI9811-5 portable $\mathrm{pH} / \mathrm{EC} / \mathrm{TDS} /$ Temperature meter (Hanna Instruments, Inc., Smithfield, RI, USA). This study 
was conducted for 7 days and the $\mathrm{pH}$ was readjusted to 7 before the application of fish feed at 9:00 a.m. next day.

\subsection{Gas Exchange Measurements}

During the third week after transplant, four representative plants were randomly selected in each treatment, and the instantaneous photosynthetic rate $\left(\mu \mathrm{mol} / \mathrm{m}^{2} / \mathrm{s}\right)$ of their young, fully expanded leaves was measured. Leaf gas-exchange measurements were performed in the greenhouse during daytime hours (between 9:00 a.m. and 2:00 p.m.) using a portable gas-exchange system (LI-6400XT; LI-COR Biosciences, Lincoln, NE, USA). The leaves were clipped inside the $6-\mathrm{cm}^{2}$ standard leaf chamber, which was assembled with a light source (LI-6400-02B; LI-COR Biosciences, Lincoln, NE, USA) and designed with red and blue LEDs (665 and $470 \mathrm{~nm}$, respectively). Illumination was supplied at a PPF of $400 \mu \mathrm{mol} / \mathrm{m}^{2} / \mathrm{s}$ by the light source under ambient temperature conditions. The reference $\mathrm{CO}_{2}$ concentration and flow rate through the chamber were $400 \mu \mathrm{mol} / \mathrm{mol}$ and $500 \mu \mathrm{mol} / \mathrm{s}$, respectively. In each treatment, the measurements of photosynthetic rate $(P n)$, stomatal conductance $(g s)$, transpiration rate $(\mathrm{Tr})$, and internal $\mathrm{CO}_{2}$ concentration $(\mathrm{Ci})$ were conducted on each plant of each species between 9:00 a.m. and 14:00 p.m. Readings were taken when the coefficient of variation (i.e., sample $\mathrm{CO}_{2}$, sample $\mathrm{H}_{2} \mathrm{O}$, and flow rate) was less than or equal to $0.2 \%$, which typically occurred within $10 \mathrm{~min}$. The intrinsic water-use efficiency (WUE) of each leaf sample was calculated by dividing $P n$ by $g s$ of that specific leaf measurement. Whole-plant photosynthetic rate was calculated by multiplying the photosynthetic rate $(P n)$ with leaf area as described in Section 2.3.

\subsection{Total Nitrogen Measurements}

All dried plant samples were filtered through a 10-mesh sieve after grinding with a Wiley Mini Mill (Thomas Scientific, Swedesboro, NJ, USA) and kept in plastic vials for total N analysis. A $30 \mathrm{mg}$ sample was measured and transferred into an empty sample tin using a clean small sampling spatula. The tin was carefully wrapped into a ball and then the total nitrogen content of a sample was measured using the C/N analyzer (FlashEA 1112, Thermo Fisher Scientific, Waltham, MA, USA) as described by Bhattacharyya et al. (2015) [24].

\subsection{Anion Measurements}

For anion nutrient analysis of water samples, the water samples, which were collected and immediately placed in a $-20{ }^{\circ} \mathrm{C}$ freezer, were thawed at room temperature, centrifuged at $12,000 \mathrm{rpm}$ for $10 \mathrm{~min}$, and then liquid supernatants were collected and subjected to anion nutrient measurement. The nutrient compositions and concentrations of processed water samples were analyzed by ion chromatography (Thermo Scientific Dionex ICS-5000, Waltham, MA, USA) equipped with anion column (IonPac AS18 column), and a conductivity detector to determine the concentration of anions (including $\mathrm{NO}_{3}-\mathrm{N}, \mathrm{NO}_{2}-\mathrm{N}, \mathrm{PO}_{4}-\mathrm{P}, \mathrm{SO}_{4}-\mathrm{S}$ ). Chromeleon data management software (version 7.1) was used for data processing.

\subsection{Experimental Design and Data Analysis}

The experimental design was a randomized complete block design (RCBD) with production system and plant species as the main factors. Six independent aquaponic systems were operated in each trial and a schematic diagram of each system was shown in Figure 1. The research layout consisted of three flow-rate treatments with two system replicates. Each flow-rate treatment consisted of six plant species and four replicates per each plant species. The experiment was repeated twice from July to October 2017 and each trial was conducted for one month. Block effect was not included in the statistical model since we observed consistent results from the two trials. Therefore, the data were pooled and analyzed using JMP v13.0 for Windows software (SAS Institute Inc., Cary, NC, USA). Statistical differences were determined using a two-way analysis of variance (ANOVA) followed by Tukey's honestly significant difference (HSD) at $p \leq 0.05$. 


\section{Results}

\subsection{Physical and Chemical Parameters of Aquaponic Solution}

Flow rate had no effect on the average dissolved oxygen (DO) concentration of aquaponic solutions (Table 2). Similarly, the average $\mathrm{pH}$ of aquaponic solution did not differ among treatments. Compared to HFR, a higher volume of base solution was required for $\mathrm{pH}$ corrections in LFR (Table 2). Meanwhile, HFR significantly decreased the average water temperature and EC during the one-month production period.

Table 2. Average values of physical and chemical water-quality parameters in fish tank for 4 weeks as affected by high (HFR, $3.3 \mathrm{~m} /$ day), medium (MFR, $2.2 \mathrm{~m} /$ day), and low (LFR, $1.1 \mathrm{~m} /$ day) flow rate.

\begin{tabular}{cccccc}
\hline $\begin{array}{c}\text { Flow Rate } \\
\text { Treatment }\end{array}$ & DO $^{\mathrm{z}}(\mathbf{m g} / \mathrm{L})$ & $\begin{array}{c}\text { Water Temperature } \\
\left({ }^{\circ} \mathbf{C}\right)\end{array}$ & EC $(\mathbf{d S} / \mathbf{m})$ & $\mathbf{p H}$ & $\begin{array}{c}\mathbf{p H} \text { Correction Solution } \\
\text { Used }(\mathbf{m L} / \mathbf{d a y})\end{array}$ \\
\hline HFR & $7.69 \pm 0.05 \mathrm{y}$ & $26.37 \pm 0.14 \mathrm{~b}^{\mathrm{x}}$ & $0.70 \pm 0.007 \mathrm{~b}$ & $6.66 \pm 0.03$ & $105.6 \pm 7.5 \mathrm{~b}$ \\
MFR & $7.71 \pm 0.05$ & $27.14 \pm 0.12 \mathrm{a}$ & $0.79 \pm 0.012 \mathrm{a}$ & $6.68 \pm 0.04$ & $117.5 \pm 9.3 \mathrm{ab}$ \\
LFR & $7.81 \pm 0.04$ & $27.02 \pm 0.13 \mathrm{a}$ & $0.76 \pm 0.011 \mathrm{a}$ & $6.49 \pm 0.04$ & $134.6 \pm 6.3 \mathrm{a}$ \\
\hline
\end{tabular}

${ }^{\mathrm{z}}$ Abbreviations: DO, dissolved oxygen; EC, electrical conductivity; HFR, high flow rate; MFR, medium flow rate; LFR, low flow rate. ${ }^{y}$ Each value in the table is the mean of 30 replicates. ${ }^{x}$ Means within columns with significant overall $P$ values followed by the same letter are not significantly different based on Tukey's honestly significant difference (HSD) test $(\alpha=0.05)$.

Weekly changes in $\mathrm{DO}$, water temperature, $\mathrm{EC}$, and $\mathrm{pH}$ indicated that flow rate treatments affected physical and chemical environment of aquaponic solutions (Figure 2). Compared to LFR, HFR maintained higher DO and lower water temperature up to one week after transplant (Figure 2A,B), and these parameters were negatively correlated with each other $\left(\mathrm{r}^{2}=0.63, p<0.001 ; \mathrm{DO}=14-\right.$ $0.24 \times$ Temp $\left.+0.022 \times(\text { Temp }-27.6)^{2}\right)$. EC did not differ among flow rate treatments in the first two weeks, but EC for HFR was lower than MFR and LFR in the last two weeks after transplant (Figure 2C). The $\mathrm{pH}$ was significantly affected with HFR highest up to two weeks but lowest at three weeks after transplant. HFR showed a slower decrease in $\mathrm{pH}$ during these weeks, indicating less $\mathrm{pH}$ fluctuations in HFR compared to those in MFR and LFR (Figure 2D).

\subsection{N Species and Other Nutrients in Aquaponic Solution}

Flow rate correlated negatively with $\mathrm{NO}_{3}-\mathrm{N}(\mathrm{r}=-0.40 ; p<0.01)$ and $\mathrm{PO}_{4}-\mathrm{P}(\mathrm{r}=-0.57 ; p<0.001)$ concentrations, suggesting a relatively higher nutrient removal rate by plants at HFR (Table 3). These results were consistent with weekly EC data, in which the EC was lower in HFR for the third and fourth weeks after transplant, indicating that crops grown at HFR remove nutrients at a higher rate or remove them at the same rate, but HFR brings fresh nutrients faster than at slower flow rates balancing the demand for limited nutrients (Figure 2C). Meanwhile, flow rate had no correlation with TAN ( $r=-0.13)$ or $\mathrm{NO}_{2}-\mathrm{N}(\mathrm{r}=0.03)$. 


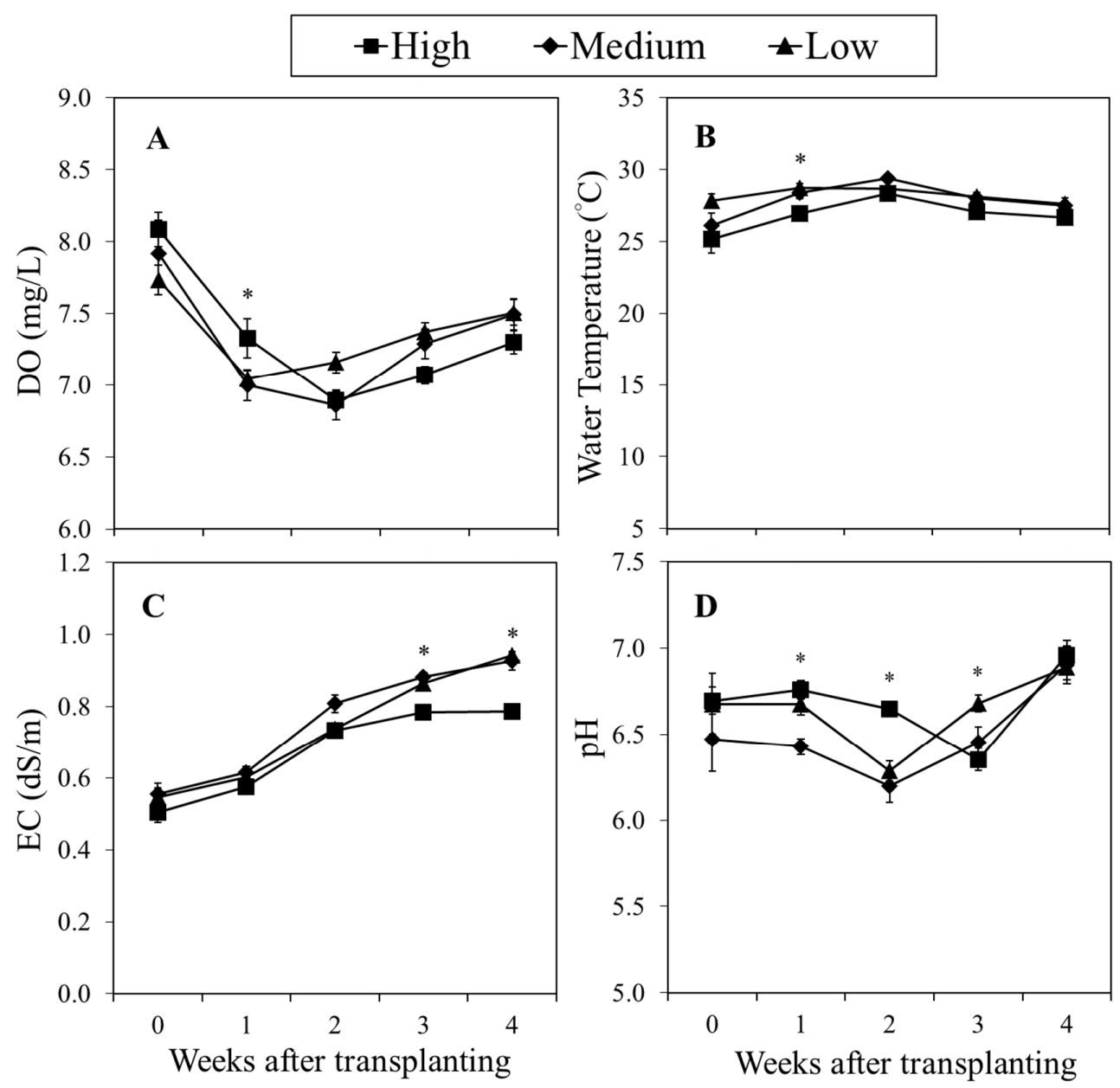

Figure 2. Weekly changes in (A) dissolved oxygen (DO), (B) water temperature, (C) electrical conductivity (EC), and (D) $\mathrm{pH}$ as affected by flow rate treatments: high (HFR, $3.3 \mathrm{~m} /$ day), medium (MFR, $2.2 \mathrm{~m} /$ day), and low (LFR, $1.1 \mathrm{~m} /$ day) flow rate. Water samples were measured daily from fish tank and grow bed in the aquaponic system. Each data point is the weekly mean of 4 replicates \pm SE. $\mathrm{ns},{ }^{*}, * *, * * *$ mean no significant or significant differences at $p \leq 0.05,0.01$, or 0.001 , respectively.

Table 3. Average concentrations of total ammonia nitrogen (TAN), nitrite $\left(\mathrm{NO}_{2}-\mathrm{N}\right)$, nitrate $\left(\mathrm{NO}_{3}-\mathrm{N}\right)$, phosphate $\left(\mathrm{PO}_{4}-\mathrm{P}\right)$, and sulfate $\left(\mathrm{SO}_{4}-\mathrm{S}\right)$ in aquaponic solution as affected by high (HFR, $3.3 \mathrm{~m} /$ day), medium (MFR, $2.2 \mathrm{~m} /$ day), and low (LFR, $1.1 \mathrm{~m} /$ day) flow rate. Water samples for analyses were collected from fish tanks.

\begin{tabular}{cccccc}
\hline Flow Rate Treatment & $\mathbf{T A N}$ & $\mathbf{N O}_{2}-\mathbf{N}$ & $\mathbf{N O}_{3}-\mathbf{N}$ & $\mathbf{P O}_{4}-\mathbf{P}$ & $\mathbf{S O}_{4}-\mathbf{S}$ \\
\hline & $\mathbf{( m g} / \mathbf{L})$ & & & & \\
\hline High Flow Rate & $1.19^{\mathrm{z}}$ & 0.45 & $31.9 \mathrm{~b} \mathrm{y}$ & $43.5 \mathrm{~b}$ & $3.56 \mathrm{~b}$ \\
Medium Flow Rate & 1.98 & 0.39 & $38.3 \mathrm{a}$ & $46.4 \mathrm{ab}$ & $5.00 \mathrm{a}$ \\
Low Flow Rate & 1.45 & 0.34 & $39.1 \mathrm{a}$ & $50.6 \mathrm{a}$ & $5.98 \mathrm{a}$ \\
$p^{\text {significance }}{ }^{\mathrm{x}}$ & $\mathrm{ns}$ & $\mathrm{ns}$ & $* * *$ & $* *$ & $*$ \\
\hline Correlation coefficient with flow rate $^{*}-0.13^{\mathrm{w}}$ & 0.03 & -0.40 & $-0.57^{\mathrm{v}}$ & -0.47 \\
$p$ significance & $\mathrm{ns}$ & $\mathrm{ns}$ & $* *$ & $* *$ & $*$
\end{tabular}

$\mathrm{z}$ Each value in the table is the mean of 4 replicates. Each replicate is the mean of 10 samples collected at different dates. ${ }^{y}$ Means within columns followed by the same letter are not significantly different based on Tukey's honestly significant difference (HSD) test $(\alpha=0.05) .{ }^{\mathrm{x}} \mathrm{ns},{ }^{*},{ }^{* *},{ }^{* * *}$ mean no significant or significant differences at $p \leq 0.05,0.01$, or 0.001 , respectively. ${ }^{\mathrm{w}}$ The results for TAN, $\mathrm{NO}_{2}-\mathrm{N}$ and $\mathrm{NO}_{3}-\mathrm{N}$ were analyzed from 60 data points using $\mathrm{HACH}$ reaction kits. ${ }^{\mathrm{v}}$ The results for $\mathrm{PO}_{4}-\mathrm{P}$ and $\mathrm{SO}_{4}-\mathrm{S}$ were analyzed using 30 data points, respectively, using ion chromatography. 
Flow rate treatment affected the concentrations of $\mathrm{N}$ species, $\mathrm{TAN}, \mathrm{NO}_{2}-\mathrm{N}$, and $\mathrm{NO}_{3}-\mathrm{N}$ in aquaponic solutions during the 4 week-production period (Figure 3). The concentration of $\mathrm{NO}_{3}-\mathrm{N}$ was higher in HFR than in LFR during the first week after transplanting and then significantly lowered over the production period (Figure 3C). Similar trends were observed for $\mathrm{PO}_{4}-\mathrm{P}$ and $\mathrm{SO}_{4}-\mathrm{S}$, in which concentrations in HFR was lower than other flow rate treatments during the last two weeks after transplant (Figure 3D,E). The initial concentration of $\mathrm{NO}_{2}-\mathrm{N}$ was higher in HFR than in LFR but the difference disappeared with increasing weeks of duration (Figure 3B).

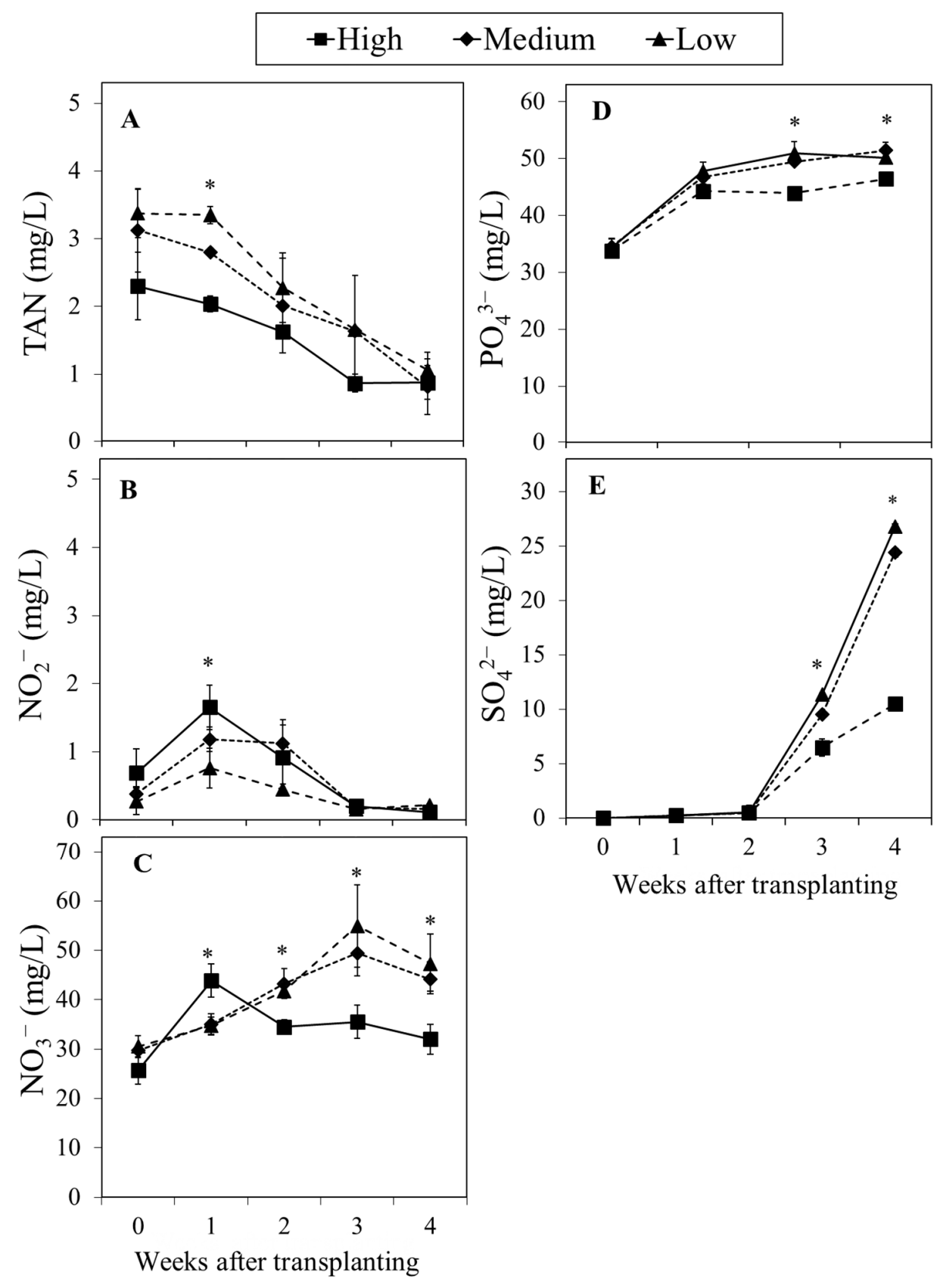

Figure 3. (A-E) Dynamic changes in (A) total ammonium nitrogen (TAN), (B) phosphate $\left(\mathrm{PO}_{4}{ }^{3-}\right)$, (C) nitrite $\left(\mathrm{NO}_{2}{ }^{-}\right),(\mathrm{D})$ sulphate $\left(\mathrm{SO}_{4}{ }^{2-}\right)$, and $(\mathrm{E})$ nitrate $\left(\mathrm{NO}_{3}{ }^{-}\right)$over 4 weeks as affected by high ( $3.3 \mathrm{~m} /$ day), medium $(2.2 \mathrm{~m} /$ day $)$, and low $(1.1 \mathrm{~m} /$ day) flow rate treatments. Data were measured every three days and weekly data were combined to show significant differences. Each data point is the mean of 4 replicates \pm SE. ns, ${ }^{*},{ }^{* *},{ }^{* * *}$ mean no significant or significant differences at $p \leq 0.05,0.01$, or 0.001 , respectively. 
When dynamic changes in $\mathrm{NH}_{4}-\mathrm{N}$ and $\mathrm{NO}_{3}-\mathrm{N}$ levels were monitored in situ in aquaponic solution for $24 \mathrm{~h}$ in the absence of plants, a NH $\mathrm{NH}_{4}-\mathrm{N}$ spike was detected immediately after the application of fish feed at 9:00 a.m., and the speed of $\mathrm{NH}_{4}-\mathrm{N}$ dissipation was affected by flow rate (Figure 4). The highest concentration of the $\mathrm{NH}_{4}-\mathrm{N}$ spike varied by flow rate, ranging from up to $101 \mathrm{mg} / \mathrm{L}$ at $\mathrm{LFR}$ to $23 \mathrm{mg} / \mathrm{L}$ at HFR (Figure 4). HFR also increased $\mathrm{NO}_{3}-\mathrm{N}$ concentration by $44 \%$ from $117 \mathrm{mg} / \mathrm{L}$ to $168 \mathrm{mg} / \mathrm{L}$. MFR and LFR also increased the $\mathrm{NO}_{3}-\mathrm{N}$ concentrations but to a lesser degree compared to HFR, increasing the concentrations by $21 \%$ (from 123 to $148 \mathrm{mg} / \mathrm{L}$ ) and $13 \%$ (from 129 to $146 \mathrm{mg} / \mathrm{L}$ ), respectively.

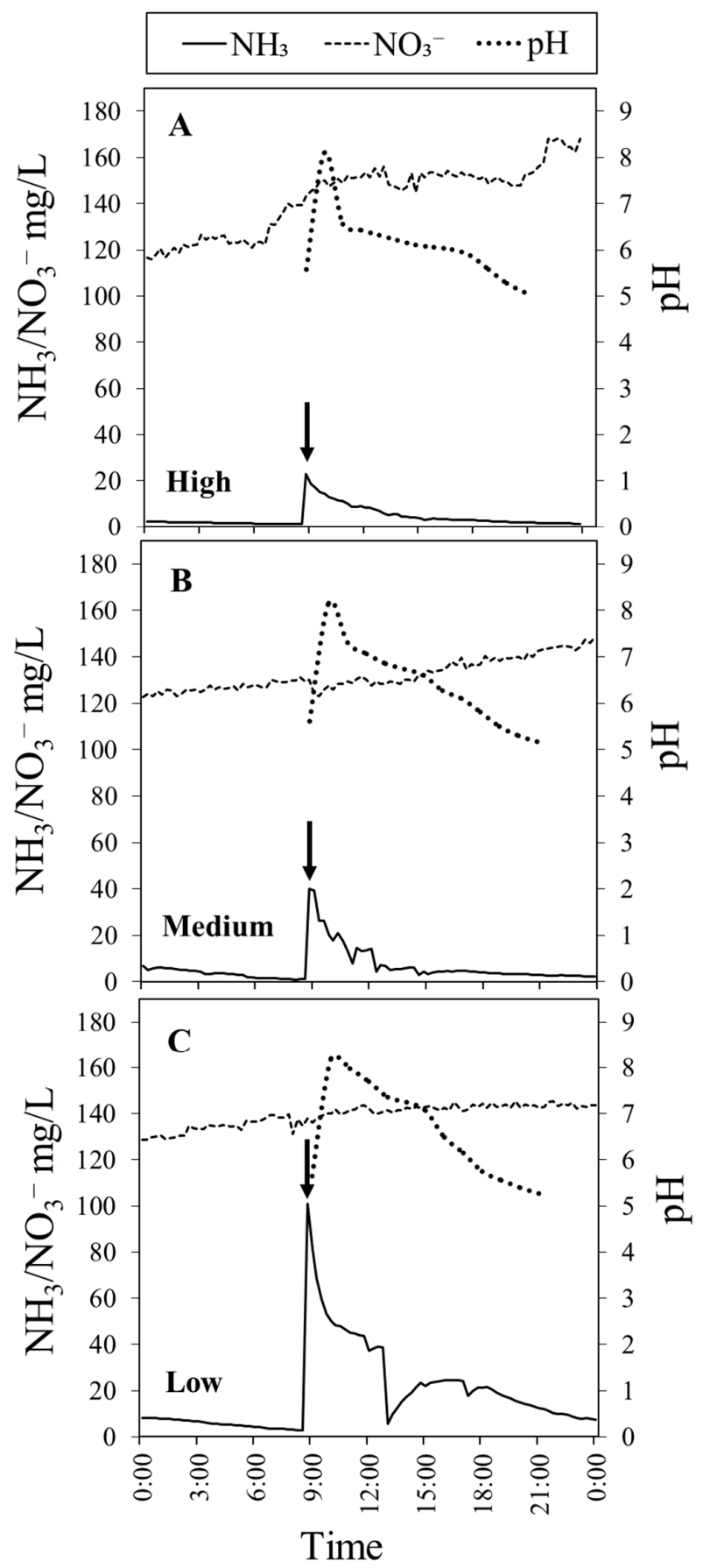

Figure 4. (A-C) Dynamic changes in ammonia $\left(\mathrm{NH}_{3}\right.$; solid line), nitrate $\left(\mathrm{NO}_{3}{ }^{-}\right.$; dashed line), and $\mathrm{pH}$ (dotted line) over $24 \mathrm{~h}$ as affected by high $(3.3 \mathrm{~m} /$ day), medium $(2.2 \mathrm{~m} /$ day), and low $(1.1 \mathrm{~m} /$ day) flow rate treatments, which were measured in the absence of plants. Arrow indicates the time when fish feed $(0.5 \%$ fish fresh weight) was applied to the fish tank. Data represent the mean of 3 replicates. 


\subsection{Plant Growth and Yield}

Six crop species were categorized into three groups based on the growth rate (expressed as $g$ total fresh weight increase per day): fast-growing (Chinese cabbage and lettuce), medium-growing (mustard and chia), and slow-growing (basil and Swiss chard) crops (Figure 5A). Regardless of crop type, the growth rate of crops was reduced by $27 \%$ when grown at LFR compared to HFR; however, the relative reduction was greater in fast-growing crops than in slow-growing crops (Figure 5B). Growth rate of fast-growing crops was similar at both HFR and MFR, while the growth rate of slow-growing crops was lower in MFR than the HFR (Figure 5B).
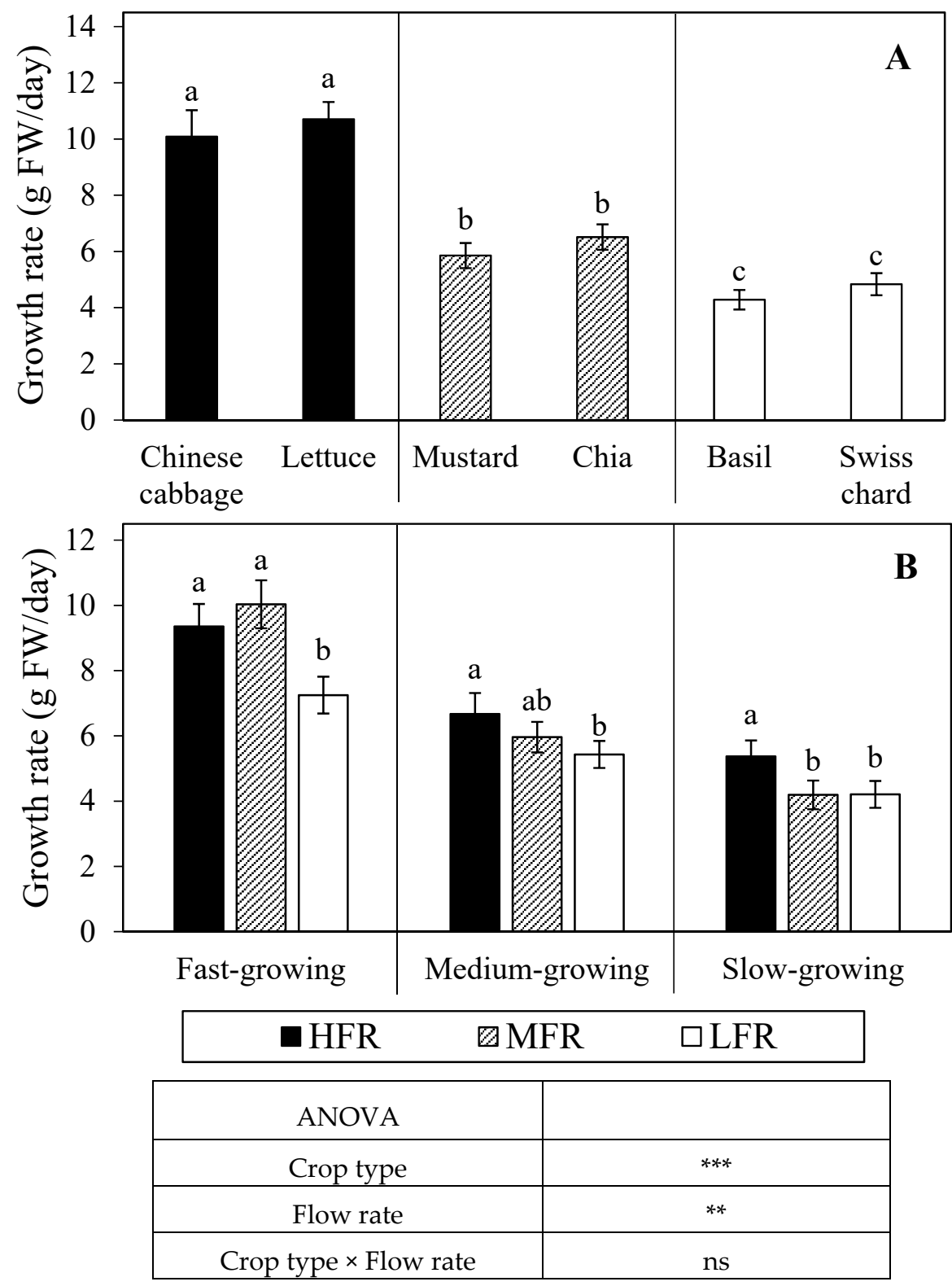

Figure 5. (A) Daily growth rate of fast-growing (Chinese cabbage, lettuce), medium-growing (mustard, chia), and slow-growing (basil, Swiss chard) crops in aquaponics and (B) their growth rate as affected by high (HFR, $3.3 \mathrm{~m} /$ day), medium (MFR, $2.2 \mathrm{~m} /$ day), and low (LFR, $1.1 \mathrm{~m} /$ day) flow rate. The same letter (A) across all species and (B) within the same crop type is not significantly different based on Tukey's honestly significant difference test $(\alpha=0.05)$. Data represent the mean of $(\mathbf{A}) 16$ replicates $\pm \mathrm{SE}$ and (B) 32 replicates \pm SE. ns, ${ }^{*},{ }^{* *},{ }^{* * *}$ mean no significant or significant differences at $p \leq 0.05,0.01$, or 0.001 , respectively. 
Plant-growth parameters of fast-, medium-, and slow-growing crops at HFR, MFR, and LFR were measured at the end of the study (Table 4). Regardless of crop type, flow rate did not impact plant height and leaf morphological characteristics such as leaf number, area, length, and specific leaf area. However, morphological differences were evident among crop types. For example, fast-growing crops had higher leaf area, but thinner leaves as demonstrated by greater SLA (thinner leaves, $p \leq 0.001$ ), but fewer leaves $(p \leq 0.001)$ than medium- and slow-growing crops. Flow rate significantly affected leaf temperature, and crops grown at HFR treatment had lower leaf temperature regardless of crop type.

Table 4. Plant growth parameters of fast-, medium-, and slow-growing crops grown in aquaponics for 4 weeks at high (HFR, $3.3 \mathrm{~m} /$ day), medium (MFR, $2.2 \mathrm{~m} /$ day), and low (LFR, $1.1 \mathrm{~m} /$ day) flow rate.

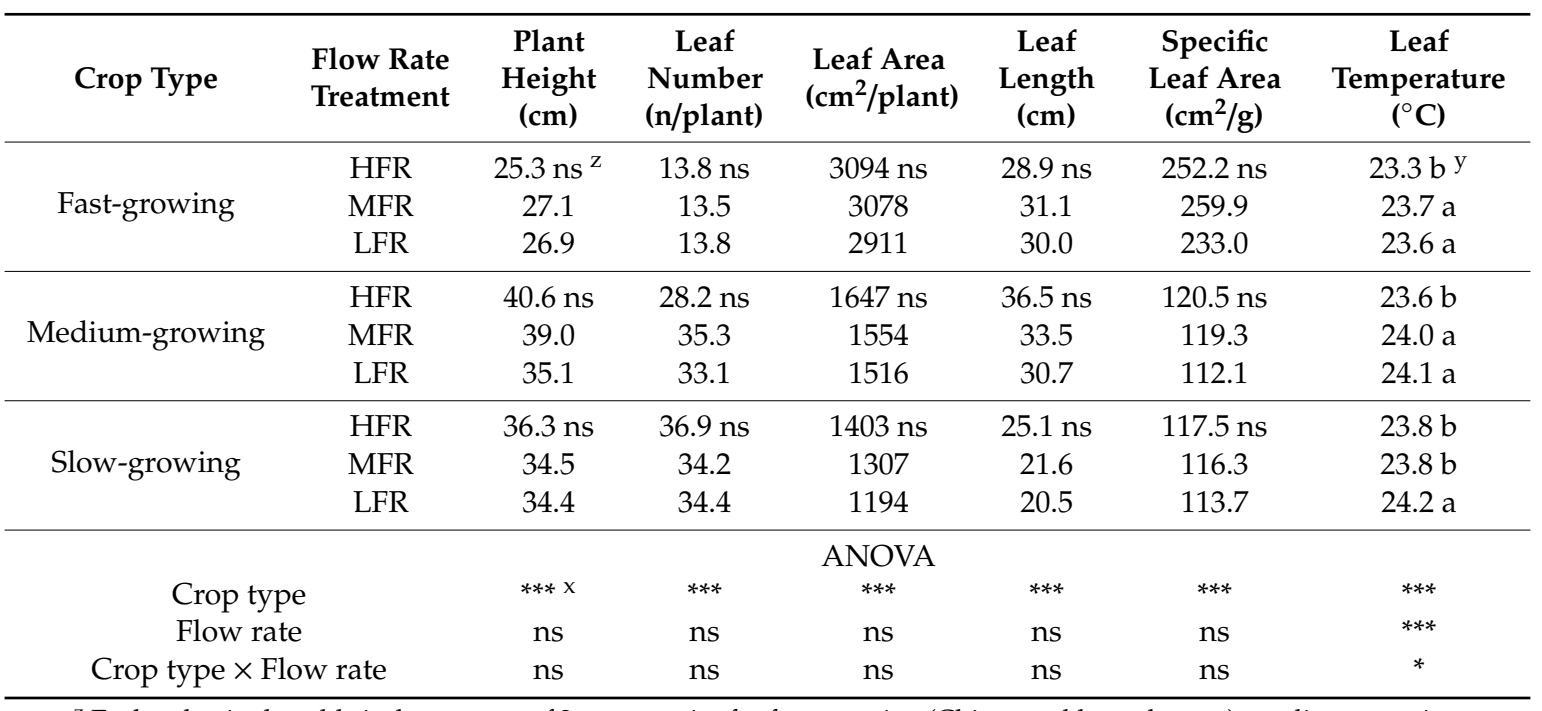

${ }^{\mathrm{z}}$ Each value in the table is the average of 2 crop species for fast-growing (Chinese cabbage, lettuce), medium-growing (mustard, chia), and slow-growing (basil, Swiss chard) crops, respectively. Each crop species consisted of 32 replicates. y Means within crop type and column followed by the same letter are not significantly different based on Tukey's honestly significant difference (HSD) test $(\alpha=0.05) .{ }^{\mathrm{x}} \mathrm{ns}$ means no significant or significant differences.

Fresh weight of different crop types was affected by flow rate. Total, shoot, and root fresh weight of fast- and medium-growing crops increased at both HFR and MFR (Table 5). While total fresh weight of slow-growing crops increased only by HFR, shoot fresh weight was not different among the flow rate treatments. In general, total and shoot dry weight of different types of crops were affected by flow rate in a similar pattern, except roots, for which dry weight was not significantly different among treatments regardless of crop type.

\subsection{Fish Production}

In our experiment, the fish were fed at a constant rate independently of their body mass, in order to maintain water quality and constant nutrient input in the system [1]. No fish death occurred during the study period. Fish stocking at HFR showed the best production performance with the highest fish biomass gain $(p \leq 0.05)$, specific growth rate (SGR) $(p \leq 0.05)$, and lowest feed conversion ratio (FCR), but no differences were detected in fish production (fish biomass gains and SGR) between HFR and MFR treatments (Table 6). 
Table 5. Fresh and dry weight of fast-growing, medium-growing, and slow-growing crops grown in aquaponics with high (HFR, $3.3 \mathrm{~m} /$ day), medium (MFR, $2.2 \mathrm{~m} /$ day), and low (LFR, $1.1 \mathrm{~m} /$ day) flow rate.

\begin{tabular}{|c|c|c|c|c|c|c|c|}
\hline \multirow{2}{*}{ Crop Type } & \multirow{2}{*}{$\begin{array}{l}\text { Flow Rate } \\
\text { Treatment }\end{array}$} & \multicolumn{3}{|c|}{ Fresh Weight (g/plant) } & \multicolumn{3}{|c|}{ Dry Weight (g/plant) } \\
\hline & & Total & Shoots & Roots & Total & Shoots & Roots \\
\hline \multirow{3}{*}{ Fast-growing } & HFR & $323.0^{\mathrm{z}} \mathrm{a}^{\mathrm{y}}$ & $287.8 \mathrm{a}$ & $35.2 \mathrm{a}$ & $9.6 \mathrm{a}$ & 8.9 a & 0.67 \\
\hline & MFR & $332.3 \mathrm{a}$ & $300.1 \mathrm{a}$ & $32.2 \mathrm{a}$ & $9.9 \mathrm{a}$ & $9.2 \mathrm{a}$ & 0.66 \\
\hline & LFR & $278.4 \mathrm{~b}$ & $249.6 \mathrm{~b}$ & $28.8 \mathrm{~b}$ & $7.1 \mathrm{~b}$ & $6.4 \mathrm{~b}$ & 0.71 \\
\hline \multirow{3}{*}{ Medium-growing } & HFR & $198.3 \mathrm{a}$ & $153.0 \mathrm{a}$ & 45.0 & $10.5 \mathrm{a}$ & $9.4 \mathrm{a}$ & 1.09 \\
\hline & MFR & $157.6 \mathrm{ab}$ & $126.7 \mathrm{ab}$ & 29.8 & $8.7 \mathrm{ab}$ & $7.6 \mathrm{ab}$ & 1.11 \\
\hline & LFR & $144.4 \mathrm{~b}$ & $101.6 \mathrm{~b}$ & 32.3 & $7.8 \mathrm{~b}$ & $6.8 \mathrm{~b}$ & 0.96 \\
\hline \multirow{3}{*}{ Slow-growing } & HFR & $154.7 \mathrm{a}$ & 115.6 & $39.1 \mathrm{a}$ & $9.3 \mathrm{a}$ & $8.3 \mathrm{a}$ & 0.95 \\
\hline & MFR & $147.9 \mathrm{~b}$ & 112.4 & $35.5 \mathrm{ab}$ & $7.1 \mathrm{~b}$ & $6.0 \mathrm{ab}$ & 1.06 \\
\hline & LFR & $123.4 \mathrm{~b}$ & 91.5 & $31.9 \mathrm{~b}$ & $6.8 \mathrm{~b}$ & $5.8 \mathrm{~b}$ & 1.01 \\
\hline & & & ANOVA & & & \\
\hline & Crop type & $* * * x$ & $* * *$ & $* * *$ & $* * *$ & $* * *$ & $* * *$ \\
\hline \multicolumn{2}{|c|}{ Flow rate } & $* * *$ & $* *$ & $* * *$ & $* *$ & $* *$ & ns \\
\hline \multicolumn{2}{|c|}{ Crop type $\times$ Flow rate } & $*$ & $*$ & ns & ns & ns & ns \\
\hline
\end{tabular}

$\mathrm{z}$ Each value in the table is the average of 2 crop species for fast-growing (Chinese cabbage, lettuce), medium-growing (mustard, chia), and slow-growing (basil, Swiss chard) crops, respectively. Each crop species consisted of 32 replicates. y Means within crop type and column followed by the same letter are not significantly different based on Tukey's honestly significant difference (HSD) test $(\alpha=0.05) .{ }^{\times} \mathrm{ns},{ }^{*}, * *, * * *$ mean no significant or significant differences at $p \leq 0.05,0.01$, or 0.001 , respectively.

Table 6. Fish production in aquaponics grown for 4 weeks at high (HFR, $3.3 \mathrm{~m} /$ day), medium (MFR, $2.2 \mathrm{~m} /$ day), and low (LFR, $1.1 \mathrm{~m} /$ day) flow rate.

\begin{tabular}{|c|c|c|c|c|c|c|c|}
\hline $\begin{array}{l}\text { Flow Rate } \\
\text { Treatment }\end{array}$ & $\begin{array}{l}\text { Fish Feed } \\
\text { Applied } \\
\text { (g) }\end{array}$ & $\begin{array}{c}\text { Initial Stocking } \\
\text { Density } \\
\left(\mathrm{kg} / \mathrm{m}^{3}\right)\end{array}$ & $\begin{array}{c}\text { Final Stocking } \\
\text { Density } \\
\left(\mathrm{kg} / \mathrm{m}^{3}\right)\end{array}$ & $\begin{array}{c}\text { Fish Biomass } \\
\text { Gain }{ }^{\mathrm{z}} \\
(\mathrm{kg} / \text { tank })\end{array}$ & $\begin{array}{c}\text { SGR }^{y} \\
(\%)\end{array}$ & FCR $^{x}$ & $\begin{array}{c}\text { Water } \\
\text { Replenishment } \\
\text { (L) }\end{array}$ \\
\hline HFR & 1980 & $19.5 \mathrm{~ns}$ & $26.5 \mathrm{~ns}$ & $2.7 \mathrm{a}$ & $3.3 \mathrm{a}$ & 0.69 & $203 \mathrm{~ns}$ \\
\hline MFR & 1980 & 19.3 & 24.4 & $1.9 \mathrm{ab}$ & $2.1 \mathrm{ab}$ & 1.06 & 177 \\
\hline LFR & 1980 & 19.3 & 22.4 & $1.2 \mathrm{~b}$ & $0.6 \mathrm{~b}$ & 1.55 & 133 \\
\hline
\end{tabular}

${ }^{\mathrm{z}}$ Means within column followed by the same letter are not significantly different based on Tukey's honestly significant difference (HSD) test $(\alpha=0.05)$. ns means no significant difference. ${ }^{\mathrm{z}}$ Specific growth rate calculated as $\mathrm{SGR}=\ln$ (final weight of fish-initial weight of fish) $\times 100 /$ days. ${ }^{\times}$Feed conversion ratio calculated as FCR $=$total weight of fish feed applied/total fish biomass increase (wet weight). ${ }^{\mathrm{w}} \mathrm{ns},{ }^{*}, * *, * *$ mean no significant or significant differences at $p \leq 0.05,0.01$, or 0.001 , respectively.

\subsection{Total Nitrogen Concentration and SPAD Value}

Regardless of crop type, total $\mathrm{N}$ content in both shoots and roots increased with higher flow rate ( $p \leq 0.05$; Table 7). Total $\mathrm{N}$ content was the highest in fast-growing followed by medium- and slow-growing crops. Likewise, flow rate affected SPAD value. Crops grown at HFR treatment had higher SPAD value across crop types. Particularly, fast-growing and medium-growing crops were more responsive to changes in flow rate, decreasing SPAD values by $25 \%$ and $31 \%$, respectively, at LFR treatment compared to those at HFR treatment, while slow-growing crops at LFR decreased it only by $9 \%$.

\subsection{Photosynthetic Parameters}

$P n, g s$, and $\operatorname{Tr}$ were higher or tended to be higher at HFR regardless of crop type (Table 8). In general, flow rate did impact $\mathrm{C} i$ and WUE, particularly in medium- and slow-growing crops. Since leaf area was greater in fast-, medium-, and slow-growing crops in decreasing order (Table 4), whole plant photosynthetic rate, as expressed as the photosynthetic rate multiplied by leaf area, was significantly greater in fast-growing crops, especially at HFR (Figure 6). In contrast, whole plant photosynthetic rate of slow-growing crops was not affected by flow rate. 
Table 7. Total nitrogen content (g/plant) and SPAD value of fast-growing, medium-growing, and slow-growing crops grown in aquaponics at high (HFR, $3.3 \mathrm{~m} /$ day), medium (MFR, $2.2 \mathrm{~m} /$ day), and low (LFR, $1.1 \mathrm{~m} /$ day) flow rate.

\begin{tabular}{|c|c|c|c|c|c|}
\hline \multirow{2}{*}{ Crop Type } & \multirow{2}{*}{ Flow Rate Treatment } & \multicolumn{3}{|c|}{ Total Nitrogen (g/plant) } & \multirow{2}{*}{ SPAD Value } \\
\hline & & Total & Shoots & Roots & \\
\hline \multirow{3}{*}{ Fast-growing } & HFR & $0.65^{\mathrm{z}} \mathrm{a}^{\mathrm{y}}$ & $0.61 \mathrm{a}$ & $0.09 \mathrm{a}$ & $19.4 \mathrm{a}$ \\
\hline & MFR & $0.58 \mathrm{~b}$ & $0.51 \mathrm{~b}$ & $0.08 \mathrm{~b}$ & $19.1 \mathrm{a}$ \\
\hline & LFR & $0.31 \mathrm{c}$ & $0.27 \mathrm{c}$ & $0.07 \mathrm{c}$ & $14.5 \mathrm{~b}$ \\
\hline \multirow{3}{*}{ Medium-growing } & HFR & $0.47 \mathrm{a}$ & $0.43 \mathrm{a}$ & $0.05 \mathrm{a}$ & $32.6 \mathrm{a}$ \\
\hline & MFR & $0.34 \mathrm{ab}$ & $0.35 \mathrm{ab}$ & $0.02 \mathrm{~b}$ & $28.1 \mathrm{~b}$ \\
\hline & LFR & $0.28 \mathrm{~b}$ & $0.27 \mathrm{~b}$ & $0.02 \mathrm{~b}$ & $22.4 \mathrm{c}$ \\
\hline \multirow{3}{*}{ Slow-growing } & HFR & $0.38 \mathrm{a}$ & $0.34 \mathrm{a}$ & $0.04 \mathrm{a}$ & $30.4 \mathrm{a}$ \\
\hline & MFR & $0.27 \mathrm{ab}$ & $0.25 \mathrm{ab}$ & $0.02 \mathrm{~b}$ & $29.7 \mathrm{ab}$ \\
\hline & LFR & $0.20 \mathrm{~b}$ & $0.18 \mathrm{~b}$ & $0.02 \mathrm{~b}$ & $27.7 \mathrm{~b}$ \\
\hline \multirow{2}{*}{\multicolumn{2}{|c|}{ Crop type }} & & ANOVA & & \\
\hline & & $* * x$ & $* * *$ & * & $* * *$ \\
\hline \multicolumn{2}{|c|}{ Flow rate } & * & $*$ & * & $* * *$ \\
\hline \multicolumn{2}{|c|}{ Crop type $\times$ Flow rate } & ns & ns & ns & ns \\
\hline
\end{tabular}

${ }^{\mathrm{z}}$ Each value in the table is the average of 2 crop species for fast-growing (Chinese cabbage, lettuce), medium-growing (mustard, chia), and slow-growing (basil, Swiss chard) crops, respectively. Each crop species consisted of 6 and 32 replicates for total nitrogen and SPAD value measurements, respectively. ${ }^{y}$ Means within crop type and column followed by the same letter are not significantly different based on Tukey's honestly significant difference (HSD) test $(\alpha=0.05) .{ }^{\times} \mathrm{ns},{ }^{*}, * * * * *$ mean no significant or significant at $p \leq 0.05,0.01$, or 0.001 , respectively.

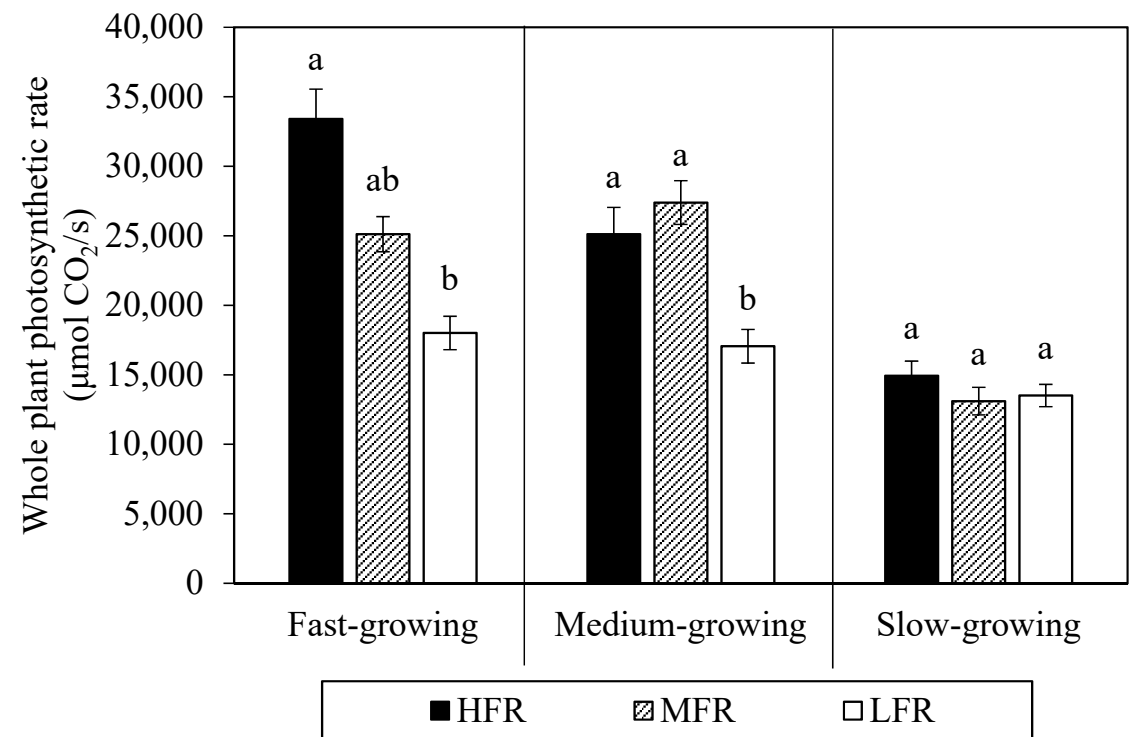

\begin{tabular}{|c|c|}
\hline ANOVA & \\
\hline Crop type & $* * *$ \\
\hline Flow rate & $* * *$ \\
\hline Crop type $\times$ Flow rate & ns \\
\hline
\end{tabular}

Figure 6. Whole plant photosynthetic rate of fast-growing (Chinese cabbage, lettuce), medium-growing (mustard, chia), and slow-growing (basil, Swiss chard) crops in aquaponics as affected by high (HFR, $3.3 \mathrm{~m} /$ day), medium (MFR, $2.2 \mathrm{~m} /$ day), and low (LFR, $1.1 \mathrm{~m} /$ day) flow rate. The same letter within the same plant category is not significantly different based on Tukey's honestly significant difference test $(\alpha=0.05)$. Data represent the mean of 18 replicates \pm SE. ns, ${ }^{*}, * * * * *$ mean no significant or significant at $p \leq 0.05,0.01$, or 0.001 , respectively. 
Table 8. Plant photosynthetic rate $(P n)$, stomatal conductance $(g s)$, transpiration rate (Tr), intercellular $\mathrm{CO}_{2}$ concentration (Ci), and intrinsic water use efficiency (WUE) of crops grown in aquaponics with high (HFR, $3.3 \mathrm{~m} /$ day), medium (MFR, $2.2 \mathrm{~m} /$ day), and low (LFR, $1.1 \mathrm{~m} /$ day) flow rate. The values are photosynthetic parameters measured at day 21 after transplanting.

\begin{tabular}{|c|c|c|c|c|c|c|}
\hline \multirow{2}{*}{ Crop Type } & \multirow{2}{*}{ Flow Rate Treatment } & $P n$ & $g s$ & $\operatorname{Tr}$ & $C i$ & WUE \\
\hline & & $\left(\mu \mathrm{mol} \mathrm{CO} 2 / \mathrm{m}^{2} / \mathrm{s}\right)$ & $\left(\mathrm{mol} \mathrm{H}{ }_{2} \mathrm{O} / \mathrm{m}^{2} / \mathrm{s}\right)$ & $\left(\mathrm{mmol} \mathrm{H}_{2} \mathrm{O} / \mathrm{m}^{2} / \mathrm{s}\right)$ & $\left(\mu \mathrm{mol} \mathrm{CO} 2 / \mathrm{m}^{2} / \mathrm{s}\right)$ & $\left(\mu \mathrm{mol} \mathrm{CO} \mathrm{CO}_{2} \mathrm{mmol} / \mathrm{H}_{2} \mathrm{O}\right)$ \\
\hline \multirow{3}{*}{ Fast-growing } & HFR & $12.87^{\mathrm{z}} \mathrm{a}^{\mathrm{y}}$ & $0.37 \mathrm{~ns}$ & $8.02 \mathrm{~ns}$ & $303.02 \mathrm{~b}$ & $1.68 \mathrm{~ns}$ \\
\hline & MFR & $11.96 \mathrm{ab}$ & 0.39 & 7.17 & $314.65 \mathrm{a}$ & 1.71 \\
\hline & LFR & $9.25 \mathrm{~b}$ & 0.33 & 6.83 & $317.72 \mathrm{a}$ & 1.41 \\
\hline \multirow{3}{*}{ Medium-growing } & HFR & $13.38 \mathrm{a}$ & $0.52 \mathrm{a}$ & $8.74 \mathrm{a}$ & $320.29 \mathrm{~ns}$ & $1.55 \mathrm{~ns}$ \\
\hline & MFR & $11.65 \mathrm{ab}$ & $0.43 \mathrm{ab}$ & $7.05 \mathrm{~b}$ & 320.83 & 1.79 \\
\hline & LFR & $10.06 \mathrm{~b}$ & $0.39 \mathrm{~b}$ & $6.60 \mathrm{~b}$ & 324.23 & 1.59 \\
\hline \multirow{3}{*}{ Slow-growing } & HFR & $14.39 \mathrm{a}$ & $0.40 \mathrm{a}$ & $8.45 \mathrm{a}$ & $298.55 \mathrm{~ns}$ & $1.86 \mathrm{~ns}$ \\
\hline & MFR & $12.54 \mathrm{ab}$ & $0.31 \mathrm{~b}$ & $5.94 \mathrm{~b}$ & 295.57 & 2.27 \\
\hline & LFR & $11.50 \mathrm{~b}$ & $0.29 \mathrm{~b}$ & $5.84 \mathrm{~b}$ & 299.31 & 2.19 \\
\hline \multicolumn{7}{|c|}{ ANOVA } \\
\hline \multicolumn{2}{|c|}{ Crop type } & $\mathrm{ns}^{\mathrm{x}}$ & $* * *$ & ns & $* * *$ & $* * *$ \\
\hline \multicolumn{2}{|c|}{ Flow rate } & $* * *$ & $* *$ & $* * *$ & $\mathrm{~ns}$ & $\mathrm{~ns}$ \\
\hline \multicolumn{2}{|c|}{ Crop type $\times$ Flow rate } & ns & ns & ns & ns & $\mathrm{ns}$ \\
\hline
\end{tabular}

z Each value in the table is the average of 2 crop species for fast-growing (Chinese cabbage, lettuce), medium-growing (mustard, chia), and slow-growing (basil, Swiss chard) crops, respectively. Each crop species consisted of 18 replicates. ${ }^{y}$ Means within crop type and column followed by the same letter are not significantly different based on Tukey's honestly significant difference (HSD) test $(\alpha=0.05)$. ns means no significant difference. ${ }^{x} \mathrm{~ns},{ }^{*}, * *{ }^{* * *}$ mean no significant or significant at $p \leq 0.05,0.01$, or 0.001 , respectively. 


\section{Discussion}

\subsection{Flow Rate Affects Water Quality in Aquaponic Systems}

Water flow rate is an important factor that determines water and nutrient availability in the root zone, thus influencing crop growth in hydroponic systems [25]. However, only limited information is available regarding water flow rate for aquaponic crop production. A wide range of flow rates have been tested for aquaponic crop production $[6,20,21]$. High flow rate, or low hydraulic retention time (HRT: $0.5 \mathrm{~h}$ ), has been recommended for aquaponic operations. Such high flow rate is considered mainly to avoid the accumulation of TAN and nitrite that are harmful for fish health [26,27] and to remove nitrite that is harmful for plant growth $[1,27,28]$. However, the suggested flow rate $\left(38.4 \mathrm{~m}^{3} / \mathrm{m}^{2} / \mathrm{day}\right.$ $\operatorname{HLR}(26.7 \mathrm{~L} / \mathrm{min}$ in our system)) is 9 to 13 times higher than what is normally suggested for hydroponic production ( 2 to $3 \mathrm{~L} / \mathrm{min}$ ). Thus, water flow rate optimization in aquaponics needs closer scrutiny for maximum nitrogen removal and crop production.

Aquaponics can be considered a wastewater-treatment system as it involves nitrification and removal of organic solids or biochemical oxygen demand [29]. The operational conditions of municipal wastewater treatment systems have been well examined [30-33], and therefore the conditions for an aquaponic system could be handled in a similar manner to improve its performance, while taking into consideration water quality parameters for fish health and well-being. Physical and biological processes of wastewater-treatment systems are known to be influenced by $\mathrm{pH}$, dissolved oxygen (DO), and hydraulic retention time (HRT), and the optimal parameters for municipal wastewater are in the $\mathrm{pH}$ ranges of 6 and 9, DO greater than $1 \mathrm{mg} / \mathrm{L}$ [34], and HRT ranging from 12 to $24 \mathrm{~h}$ (as low as our LFR) [35], which are necessary for biological nitrification-denitrification processes to occur.

In this study, we demonstrated that water flow rate makes spatial and temporal changes of water physical and chemical parameters in aquaponic solution not only for $\mathrm{N}$ species, but also DO, water temperature, EC, and $\mathrm{pH}$. Flow rate at $3.3 \mathrm{~m}^{3} / \mathrm{m}^{2} /$ day HLR was sufficient for high water quality and aquaponic crop production regardless of crop type. Previous research on life cycle assessment indicated that the electricity required for a water pump is a major contributing factor to the environmental impact in aquaponics [7], and their impact assessment analysis showed that electricity was a highly sensitive factor and the small reduction on electricity use contributed to a corresponding benefit to the environment. Our study demonstrated that flow rate optimization can benefit the reduction of electricity consumption and present a significant contribution to the maximization of aquaponic system performance.

We found that LFR (HLR: $1.1 \mathrm{~m}^{3} / \mathrm{m}^{2} /$ day; HRT: $17 \mathrm{~h}$ ) led to the temporal increase in harmful $\mathrm{N}$ species in aquaponic solution and temporal decrease in nitrification (Figures 3 and 4), and therefore negatively affecting the growth and yield of plant and fish crops (Tables 5 and 6). Particularly, $\mathrm{NH}_{3}-\mathrm{N}$ accumulated up to $100 \mathrm{mg} / \mathrm{L}$ and high levels over $20 \mathrm{mg} / \mathrm{L}$ lasted for a prolonged period of time (Figure 4), which was also associated with slower $\mathrm{pH}$ drops and slower nitrification (Figure 4). Nitrification is a well-known biological process by which ammonia or ammonium is sequentially oxidized to nitrite and nitrate. The process is primarily mediated by two groups of autotrophic nitrifying bacteria and, as a result, $\mathrm{pH}$ decreases [36]. The $\mathrm{pH}$ was quickly lowered by HFR compared to MFR and LFR (Figure 4), which is most likely caused by a higher nitrification rate as a result of more substrate for the process being delivered to the biofilter in HFR treatment. Meanwhile, LFR maintained high $\mathrm{pH}$ levels in fish tank for an extended period. The slower $\mathrm{pH}$ drop and slower conversion to nitrate at LFR are considered as the results of reduced microbial activity, which is possibly associated with reduced DO level (Figure 2).

In fact, HFR employed in this study was found to be effective in maintaining crop yield and quality to the levels found in hydroponics if other parameters are met [1]. Considering that $\mathrm{NH}_{3}-\mathrm{N}$ concentration is highly dependent on flow rate, water flow rate can be designed such that $\mathrm{NH}_{3}-\mathrm{N}$ is fully dissipated in short time rather than set at a constant level. For example, daily water flow cycle, such as a higher flow rate immediately after feeding followed by lower flow rate for the rest of the day, 
may improve water quality and maintain crop yield and quality similar to or even greater than what was demonstrated in this study.

Notably, HLR not only significantly reduced water temperature but also decreased leaf temperature of the crops regardless of crop type. In a closed recirculating aquaponic system, the initial amount of energy (thermal energy and kinetic energy) in water is assumed to be the same among different aquaponic systems used in our study. According to energy conservation law (first law of thermodynamics), thermal energy transfers faster into kinetic energy when water moves with higher flow rate [37]. This may explain how higher flow rate reduced water temperature of aquaponic solution as observed in our study. We found that crops had lower leaf temperature and higher $\mathrm{Tr}$ and $\mathrm{Pn}$ when they were grown at HFR (Tables 4 and 8). Crop species used in our study are cold-season crops, of which growth can be affected by air or root zone temperatures [38,39]. HFR reduced leaf temperature which appeared to have a similar effect as low root zone or low air temperatures, promoting crop yield via increasing photosynthetic rates. Some studies demonstrated the effects of high flow rate on water temperatures. For example, Nuwansi et al. (2016) [40] investigated the effect of three different flow rates $(0.8,2.4$, and $4 \mathrm{~L} / \mathrm{min}$; HLR is unknown) on the growth of water spinach (Ipomoea aquatica) in aquaponics systems culturing koi carp (Cyprinus carpio var. koi) and goldfish (Carassius auratus) and observed that water temperature decreased when flow rate increased from 0.8 to $2.4 \mathrm{~L} / \mathrm{min}$. However, the results were not conclusive because there was no difference between 0.8 and $4 \mathrm{~L} / \mathrm{min}$ flow rate treatments. Shete et al. (2016) also observed that water temperature had a decreasing trend when hydraulic loading rate (HLR) increased from 3 to $12 \mathrm{~m}^{3} / \mathrm{m}^{2} /$ day in an aquaponic system with Common carp (Cyprinus carpio) and Mint (Mentha arvensis).

Outdoor pond-scale recirculating systems usually use constructed wetlands to treat and reuse aquaculture wastewater [18,41-44]. Retention time is one of the key parameters influencing the performance of constructed wetlands as a biofilter for aquaculture wastewater treatment [45]. Some studies suggest that the performance of the eco-technology is generally a function of HLR, and the selection of proper HLR is required for maximum nutrient removal [46] because $\mathrm{N}$ transformations by microbes (mainly ammonification, nitrification, and denitrification) can be increased by a longer contact time between microbes and plant roots [47]. There are a few reports on the negative impact of a high water flow rate in a pond-scale recirculating system. Lin et al. (2002) [10] and Schulz et al. (2003) [48] found that the performance of $\mathrm{N}$ removal rate decreased with high HLR $\left(\geq 1 \mathrm{~m}^{3} / \mathrm{m}^{2} /\right.$ day). Gao et al. (2011) [49] also found that $1 \mathrm{~m}^{3} / \mathrm{m}^{2} /$ day HLR (2-d HRT) reduced the contact time of microorganisms with aquaculture wastewater and roots. Although direct evidence is lacking in aquaponic studies, a similar concept can be applied, such that an exceptionally high flow rate reduces the contact time between plant roots and nutrients in small-scale recirculating aquaponic systems. Collective information suggests that a high water flow rate diminished $\mathrm{N}$ transformation by the microbial community [50,51], $\mathrm{N}$ removal rate by plants [52-54], and plant biomass [18,53,55]. For example, in a study comparing three flow rates (1.0, 1.5, and $3.2 \mathrm{~L} / \mathrm{min} ; 2.5,1.7,0.78 \mathrm{~h} \mathrm{HRT}$ ), spinach beet (Beta vulgaris var. bengalensis) yield increased with increasing flow rate from $1.0 \mathrm{~L} / \mathrm{min}$ to $1.5 \mathrm{~L} / \mathrm{min}$, but decreased when flow rate was further increased to $3.2 \mathrm{~L} / \mathrm{min}$ [56]. High flow rate (HLR: $3.2 \mathrm{~m}^{3} / \mathrm{m}^{2} /$ day) in a recirculating aquaponic system negatively affected $\mathrm{NO}_{3}-\mathrm{N}$ and total $\mathrm{P}$ removal rates of water spinach (Ipomoea aquatica) as compared to lower flow rates [57]. Meanwhile, mint growth and yield was improved by a much higher flow rate of 12,000 L/day (HRT: $1.2 \mathrm{~h}$ ) than the aforementioned flow rate but not by 24,000 L/day (HRT: $0.6 \mathrm{~h}$ ) [20]. Since only one plant species was employed in these studies, it is not clear if the flow rate is plant-specific or can be universally applied to any plant crops.

\subsection{Hydraulic Loading Rate at $3.3 \mathrm{~m}^{3} / \mathrm{m}^{2} /$ Day is Sufficient to Promote Crop Growth and Yield}

Our investigations on the effects of flow rate on dynamic changes in $\mathrm{N}$ species showed that the concentrations of $\mathrm{NO}_{3}-\mathrm{N}$ increased in accordance with the dissipation of $\mathrm{NH}_{3}-\mathrm{N}$ spike and $\mathrm{DO}$ increased with increasing flow rate, especially during the first two weeks after transplant (Figure 2). These changes in water physical and chemical environments positively affected plant growth as 
demonstrated in the increased SPAD value, total N content, and whole plant photosynthetic rate, facilitating crops to effectively remove nutrients from aquaponic solution through higher biomass production (Table 2). These results support our contention that HFR creates water environment for enhanced microbial activities and promotes nitrification, leading to a higher crop yield and quality.

Dynamic changes of $\mathrm{N}$ species in root environment also somewhat increased fresh root weight (Table 5). Higher $\mathrm{NO}_{3}-\mathrm{N}$ availability could increase both root production and root nutrient uptake capacity $[58,59]$. Further investigation about flow-rate-effect on plant root architecture and physiological functions will decipher these results. Nutrient gradients (physical and metabolic gradients) were essential to sustain primary production in the aquatic environment [60]. Contrarily, a lower flow rate probably limited the transport and spatial availability of $\mathrm{N}$ and $\mathrm{P}$ as well as other nutrients to the root zone, thus reducing crop growth. In fact, Warwick and Hill (1988) [61] demonstrated that a low flow rate prevented the formation of micro-gradients of nutrients around the roots, where nutrient depletion occurs on a very small spatial scale.

Our study found that the flow rate used for HFR treatment (HLR: $3.3 \mathrm{~m}^{3} / \mathrm{m}^{2} /$ day) was sufficient to achieve not only a higher removal rate of $\mathrm{N}$ and $\mathrm{P}$ and better plant growth (Tables 3 and 5), but also a higher fish yield (Table 6). Similar results were found in an aquaponic study with water spinach and African catfish, in which a water flow rate of $1.6 \mathrm{~L} / \mathrm{min}$ (HLR: $1.28 \mathrm{~m}^{3} / \mathrm{m}^{2} /$ day) gave the best production performance of fish than a lower flow rate of $0.8 \mathrm{~L} / \mathrm{min}$ (HLR: $0.64 \mathrm{~m}^{3} / \mathrm{m}^{2} /$ day) [21]. However, their study used different size fish among the treatments, so the results cannot be used to fully justify the reason for the improved fish yield at the high flow rate.

Although each aquaponic component (fish tank, sediment tank, biofilter, and hydroponic unit) influences the entire production process in a recirculating aquaponic system, the hydroponic component can directly affect water quality by actively removing toxic $\mathrm{N}$ species, and this is essential for fish growth [62]. It is apparent that the flow rate used for HFR treatment improves performance and yield of plant crops, which can increase fish yield via improved water quality. Initially, the primary purpose of an aquaponic system was to produce fish, with vegetables being a byproduct for water treatment [63]. However, vegetables are reported to be the major revenue source in tilapia-based aquaponic systems [64]. It should be noted that optimizing flow rate for plant crops is critical to increase fish crop yield in a recirculating aquaponic system, which can lead to a highly profitable aquaponic crop production.

\subsection{Plants Require Different Flow Rate Based on Their Growth Rate}

When optimizing flow rate in aquaponics, crop nutritional requirements and uptake ability need to be taken into consideration, a factor that has not been investigated in previous studies [13,65-67]. Some studies demonstrated variations in crop growth as affected by flow rate. Buzby et al. (2016) reported that a flow rate at $18.9 \mathrm{~m} / \mathrm{L}$ reduced biomass of most plant species except cilantro (Coriandrum sativum "Santo"), parsley (Petroselinum crispum "Darki"), and minutina (Plantago coronopus). Similarly, Diem et al. (2017) found that $400 \%$ recirculation rates reduced the yield of water spinach, but not of canna, especially at high fish stock density. However, their studies did not discuss the causes of the variations among plant species. Although some studies examined the importance of optimizing pump size and flow rate to reduce energy demands at system-level (i.e., life cycle assessment) $[68,69]$, crop growth rate was not taken into consideration.

Our results showed that fresh weight, dry weight, and total $\mathrm{N}$ concentration were higher in fast-, medium-, and slow-growing crop species in decreasing order. Regardless of nutrient availability, fast-growing crop species have a greater capacity to uptake nutrients and grow faster than slow-growing crop species [70] and such characteristics may explain the growth variations in association with flow rate observed in our study. Slow-growing species are characterized by the lower specific leaf area (thicker leaves) due to relatively high concentrations of cell-wall material and quantitative secondary compounds, which consume more investment [71,72], but leaf longevity is longer for slow-growing species, which could diminish nutrient losses and contribute to success in nutrient-limited habitats [70]. 
It is likely that there are trade-offs between growth potential and crop performance under adverse conditions. The SPAD value was lower in fast-, medium-, and slow-growing crops in increasing order, which may be a result of tissue $\mathrm{N}$ dilution of fast-growing crops as nutrient concentrations can be reduced by the accumulation of new biomass, which has been discussed in previous studies [73-75].

Our study provides practical implications on how to optimize flow rate in aquaponic systems. HLR of at least $2.2 \mathrm{~m}^{3} / \mathrm{m}^{2} /$ day should be maintained for the growth of fast-growing crops, but lower HLR can be used for slow-growing crops as its growth and performance (i.e., shoot fresh weight and whole plant photosynthesis) are less affected by the flow rate. Future research will need to investigate the optimal flow rate for slow growing crops in aquaponic systems. Overall, careful considerations on the crop species should be given when optimizing water flow rate in aquaponics as the plant species vary in their growth rate, nutrient removal capacity, and growth stage for harvest.

\section{Conclusions}

Evidence was presented in this study that the water flow rate can be optimized to potentially reduce the pumping requirement and enhance crop production in recirculating aquaponic systems. In aquaponic systems, a hydraulic loading rate at $3.3 \mathrm{~m}^{3} / \mathrm{m}^{2} /$ day was sufficient to significantly reduce the exposure duration of plant roots and fish to detrimental levels of ammonia. The hydraulic loading rate also positively affected $\mathrm{pH}, \mathrm{DO}$, and water temperature for nitrification, ultimately increasing plant and fish production. This study suggests practical considerations that favor energy savings and higher profitability by improving crop biomass production. Flow rate optimization should consider the growth rate of plant species cultured in aquaponics. In summary, in a small-scale aquaponic system, a hydraulic loading rate for fast- and medium-growing crops can be set at 3.3 to $2.2 \mathrm{~m}^{3} / \mathrm{m}^{2} /$ day $(6$ to $9 \mathrm{~h}$ hydraulic retention time) to improve crop performance and yield, while that for slow-growing crops may be lowered below $2.2 \mathrm{~m}^{3} / \mathrm{m}^{2} /$ day ( $6 \mathrm{~h}$ hydraulic retention time) due to its less significant effect.

Supplementary Materials: The following are available online at http://www.mdpi.com/2311-7524/6/1/9/s1, Table S1: Plant-growth parameters of fast-growing, medium-growing, and slow-growing crops measured at day 0.

Author Contributions: T.Y. conducted experiment, collected data, undertook data analysis and interpretation, and drafted the manuscript. H.-J.K. coordinated and supervised the research and completed the final version of the manuscript. All authors have read and agreed to the published version of the manuscript.

Funding: This research was supported by Indiana Water Resources Research Center (IWRRC) \& US Geological Survey 104b grants; USDA National Institute of Food and Agriculture, under award number 2013-67019-21376; USDA National Institute of Food and Agriculture, Hatch/Multi State project NE-1335 Resource Management in Commercial Greenhouse Production; Purdue University Research Funds.

Acknowledgments: We are grateful to N.D. and D.L. for their technical assistance; Y.-J.W., G.Z., B.W., and J.B. for their help with crop management and data collection; and C.M., P.B., and S.B. for their helpful discussions during the research.

Conflicts of Interest: The authors declare that they have no conflicts of interest.

\section{References}

1. Yang, T.; Kim, H.-J. Nutrient management regime affects water quality, crop growth, and nitrogen use efficiency of aquaponic systems. Sci. Hortic. 2019, 256, 108619. [CrossRef]

2. Rakocy, J.; Shultz, R.; Bailey, D.; Thoman, E. Aquaponic Production of Tilapia and Basil: Comparing a Batch and Staggered Cropping System. Acta Hortic. 2004, 648, 63-69. [CrossRef]

3. Hargreaves, J.A. Nitrogen biogeochemistry of aquaculture ponds. Aquaculture 1998, 166, 181-212. [CrossRef]

4. Rakocy, J.E. Integrating tilapia culture with vegetable hydroponics in recirculating systems. Tilapia Aquac. Am. 1997, 1, 163-184.

5. Love, D.C.; Fry, J.P.; Genello, L.; Hill, E.S.; Frederick, J.A.; Li, X.; Semmens, K. An International Survey of Aquaponics Practitioners. PLoS ONE 2014, 9, e102662. [CrossRef]

6. Somerville, C.; Cohen, M.; Pantanella, E.; Stankus, A.; Lovatelli, A. Small-scale aquaponic food production Integrated fish and plant farming. FAO Fish. Aquac. Tech. Pap. 2014, 589, 1-262. 
7. Boxman, S.E.; Zhang, Q.; Bailey, D.; Trotz, M.A. Life Cycle Assessment of a Commercial-Scale Freshwater Aquaponic System. Environ. Eng. Sci. 2017, 34, 299-311. [CrossRef]

8. Caron, J.; Riviere, L.M.; Charpentier, S.; Renault, P.; Michel, J.C. Using TDR to estimate hydraulic conductivity and air entry in growing media and sand. Soil Sci. Soc. Am. J. 2002, 66, 373-383. [CrossRef]

9. Raviv, M.; Wallach, R.; Silber, A.; Medina, S.; Krasnovsky, A. The Effect of Hydraulic Characteristics of Volcanic Materials on Yield of Roses Grown in Soilless Culture. J. Am. Soc. Hortic. Sci. 1999, 124, 205-209. [CrossRef]

10. Lin, Y.-F.; Jing, S.-R.; Lee, D.-Y.; Wang, T.-W. Nutrient removal from aquaculture wastewater using a constructed wetlands system. Aquaculture 2002, 209, 169-184. [CrossRef]

11. Allaire-Leung, S.E.; Gupta, S.C.; Moncrief, J.F. Water and solute movement in soil as influenced by macropore characteristics-1. Macropore continuity. J. Contam. Hydrol. 2000, 41, 283-301. [CrossRef]

12. Mamat; Sintawardani, N.; Astuti, J.T.; Nilawati, D.; Wulan, D.R.; Muchlis; Sriwuryandari, L.; Sembiring, T.; Jern, N.W. Flow rate analysis of wastewater inside reactor tanks on tofu wastewater treatment plant. IOP Conf. Series Earth Environ. Sci. 2017, 60, 12023. [CrossRef]

13. Khater, E.S.G.; Ali, S.A. Effect of Flow Rate and Length of Gully on Lettuce Plants in Aquaponic and Hydroponic Systems. J. Aquac. Res. Dev. 2015, 6, 318.

14. Nakano, Y.; Watanabe, S.-I.; Okano, K.; Tatsumi, J. Effects of Flow Rate of Hydroponic Nutrient Solution on Growth and Ion Uptake by Tomato Seedlings. Environ. Control. Boil. 2001, 39, 199-204. [CrossRef]

15. Resh, H.M. Hydroponic Food Production: A Definitive Guidebook for the Advanced Home Gardener and the Commercial Hydroponic Grower, 7th ed.; CRC Press: Boca Raton, FL, USA, 2013.

16. Al-Tawaha, A.R.; Al-Karaki, G.; Al-Tawaha, A.R.; Sirajuddin, S.N.; Makhadmeh, I.; Wahab, P.E.M.; Youssef, R.A.; Al Sultan, W.; Massadeh, A. Effect of water flow rate on quantity and quality of lettuce (Lactuca sativa L.) in nutrient film technique (NFT) under hydroponics conditions. Bulg. J. Agric. Sci. 2018, 24, 793-800.

17. Zeroni, M.; Gale, J.; Ben-Asher, J. Root aeration in a deep hydroponic system and its effect on growth and yield of tomato. Sci. Hortic. 1983, 19, 213-220. [CrossRef]

18. Lin, Y.-F.; Jing, S.-R.; Lee, D.-Y.; Chang, Y.-F.; Chen, Y.-M.; Shih, K.-C. Performance of a constructed wetland treating intensive shrimp aquaculture wastewater under high hydraulic loading rate. Environ. Pollut. 2005, 134, 411-421. [CrossRef]

19. Xu, J.; Shi, Y.; Zhang, G.; Liu, J.; Zhu, Y. Effect of hydraulic loading rate on the efficiency of effluent treatment in a recirculating puffer aquaculture system coupled with constructed wetlands. J. Ocean Univ. China 2014, 13, 146-152. [CrossRef]

20. Shete, A.; Verma, A.; Chadha, N.; Prakash, C.; Peter, R.; Ahmad, I.; Nuwansi, K. Optimization of hydraulic loading rate in aquaponic system with Common carp (Cyprinus carpio) and Mint (Mentha arvensis). Aquac. Eng. 2016, 53-57. [CrossRef]

21. Endut, A.; Jusoh, A.; Ali, N.; Nik, W.W.; Hassan, A. Effect of flow rate on water quality parameters and plant growth of water spinach (Ipomoea aquatica) in an aquaponic recirculating system. Desalin. Water Treat. 2009, 5, 19-28. [CrossRef]

22. Wongkiew, S.; Popp, B.N.; Kim, H.-J.; Khanal, S.K. Fate of nitrogen in floating-raft aquaponic systems using natural abundance nitrogen isotopic compositions. Int. Biodeterior. Biodegrad. 2017, 125, 24-32. [CrossRef]

23. Kim, H.-J.; Yang, T.; Lin, M.-Y.; Langenhoven, P. Plant propagation for successful hydroponic production(C) Acta Hortic. 2018, 109-116. [CrossRef]

24. Bhattacharyya, T.; Ray, S.K.; Maurya, U.K.; Chandran, P.; Pal, D.K.; Durge, S.L.; Nimkar, A.M.; Sheikh, S.M.; Kuchankar, H.W.; Telpande, B.; et al. Carbon and nitrogen estimation in soils: Standardizing methods and internal standards for C/N analyzer. J. Indian Chem. Soc. 2015, 92, 263-269.

25. Blok, C.; Jackson, B.E.; Guo, X.; De Visser, P.H.B.; Marcelis, L.F.M. Maximum Plant Uptakes for Water, Nutrients, and Oxygen are not Always Met by Irrigation Rate and Distribution in Water-based Cultivation Systems. Front. Plant Sci. 2017, 8, 91. [CrossRef] [PubMed]

26. Cripps, S.J.; Bergheim, A. Solids management and removal for intensive land-based aquaculture production systems. Aquac. Eng. 2000, 22, 33-56. [CrossRef]

27. Danaher, J.J.; Shultz, R.C.; Rakocy, J.E.; Bailey, D.S. Alternative Solids Removal for Warm Water Recirculating Raft Aquaponic Systems. J. World Aquac. Soc. 2013, 44, 374-383. [CrossRef] 
28. Li, W.; Liu, X.; Khan, M.A.; Yamaguchi, S. The effect of plant growth regulators, nitric oxide, nitrate, nitrite and light on the germination of dimorphic seeds of Suaeda salsa under saline conditions. J. Plant Res. 2005, 118, 207-214. [CrossRef]

29. Gräber, A.; Junge, R. Aquaponic Systems: Nutrient recycling from fish wastewater by vegetable production. Desalination 2009, 246, 147-156. [CrossRef]

30. Klinger, D.; Naylor, R. Searching for Solutions in Aquaculture: Charting a Sustainable Course. Annu. Rev. Environ. Resour. 2012, 37, 247-276. [CrossRef]

31. Longo, S.; D'Antoni, B.M.; Bongards, M.; Chaparro, A.; Cronrath, A.; Fatone, F.; Lema, J.M.; Mauricio-Iglesias, M.; Soares, A.; Hospido, A. Monitoring and diagnosis of energy consumption in wastewater treatment plants. A state of the art and proposals for improvement. Appl. Energy 2016, 179, 1251-1268. [CrossRef]

32. Sun, Y.; Chen, Z.; Wu, G.; Wu, Q.; Zhang, F.; Niu, Z.; Hu, H.-Y. Characteristics of water quality of municipal wastewater treatment plants in China: Implications for resources utilization and management. J. Clean. Prod. 2016, 131, 1-9. [CrossRef]

33. Zhang, Q.; Yang, W.; Ngo, H.; Guo, W.; Jin, P.; Dzakpasu, M.; Yang, S.; Wang, Q.; Wang, X.; Ao, D. Current status of urban wastewater treatment plants in China. Environ. Int. 2016, 92, 11-22. [CrossRef] [PubMed]

34. Tchobanoglous, G.; Burton, F.L.; Stensel, H.D. Wastewater Engineering: Treatment and Reuse, 4th ed.; Metcalf \& Eddy, Inc., Tata McGraw-Hill Publishing Co. Ltd.: New York, NY, USA, 2003.

35. Chan, Y.J.; Chong, M.F.; Law, C.L.; Hassell, D. A review on anaerobic-aerobic treatment of industrial and municipal wastewater. Chem. Eng. J. 2009, 155, 1-18. [CrossRef]

36. Szwerinski, H.; Arvin, E.; Harremoes, P. pH-decrease in nitrifying biofilms. Water Res. 1986, 20, 971-976. [CrossRef]

37. Budiansky, B.; Rice, J.R. Conservation Laws and Energy-Release Rates. J. Appl. Mech. 1973, 40, $201-203$. [CrossRef]

38. Lester, G.E. Environmental regulation of human health nutrients (Ascorbic acid, beta-carotene, and folic acid) in fruits and vegetables. Hortscience 2006, 41, 59-64. [CrossRef]

39. Liu, X.; Huang, B. Root physiological factors involved in cool-season grass response to high soil temperature. Environ. Exp. Bot. 2005, 53, 233-245. [CrossRef]

40. Nuwansi, K.K.T.; Verma, A.K.; Prakash, C.; Tiwari, V.K.; Chandrakant, M.H.; Shete, A.P.; Prabhath, G.P.W.A. Effect of water flow rate on polyculture of koi carp (Cyprinus carpio var. koi) and goldfish (Carassius auratus) with water spinach (Ipomoea aquatica) in recirculating aquaponic system. Aquac. Int. 2016, 24, 385-393. [CrossRef]

41. Konnerup, D.; Trang, N.T.D.; Brix, H. Treatment of fishpond water by recirculating horizontal and vertical flow constructed wetlands in the tropics. Aquaculture 2011, 313, 57-64. [CrossRef]

42. Tilley, D.R.; Badrinarayanan, H.; Rosati, R.; Son, J. Constructed wetlands as recirculation filters in large-scale shrimp aquaculture. Aquac. Eng. 2002, 26, 81-109. [CrossRef]

43. Zhang, S.-Y.; Li, G.; Chang, J.-J.; Li, X.-L.; Tao, L. Aerated enhanced treatment of aquaculture effluent by three-stage, subsurface-flow constructed wetlands under a high loading rate. Pol. J. Environ. Stud. 2014, 23, 1821-1830.

44. Zhang, S.-Y.; Li, G.; Wu, H.-B.; Liu, X.-G.; Yao, Y.-H.; Tao, L.; Liu, H. An integrated recirculating aquaculture system (RAS) for land-based fish farming: The effects on water quality and fish production. Aquac. Eng. 2011, 45, 93-102. [CrossRef]

45. Shpigel, M.; Ben-Ezra, D.; Shauli, L.; Sagi, M.; Ventura, Y.; Samocha, T.; Lee, J. Constructed wetland with Salicornia as a biofilter for mariculture effluents. Aquaculture 2013, 412, 52-63. [CrossRef]

46. Li, X.-N.; Song, H.-L.; Lu, X.-W.; Xie, X.-F.; Inamori, Y. Characteristics and mechanisms of the hydroponic bio-filter method for purification of eutrophic surface water. Ecol. Eng. 2009, 35, 1574-1583. [CrossRef]

47. Buhmann, A.; Papenbrock, J. Biofiltering of aquaculture effluents by halophytic plants: Basic principles, current uses and future perspectives. Environ. Exp. Bot. 2013, 92, 122-133. [CrossRef]

48. Schulz, C.; Gelbrecht, J.; Rennert, B. Treatment of rainbow trout farm effluents in constructed wetland with emergent plants and subsurface horizontal water flow. Aquaculture 2003, 217, 207-221. [CrossRef]

49. Gao, F.; Li, C.; Jin, W.-H. Study on saline aquaculture wastewater treatment by constructed wetland. In Proceedings of the 2011 International Conference on Electronics, Communications and Control (ICECC), Ningbo, China, 9-11 September 2011; pp. 3938-3941. 
50. Effendi, H.; Utomo, B.A.; Sulaeman, N. Combination of water spinach (Ipomea aquatica) and bacteria for freshwater cryfish red claw (Cherax quadricarinatus) culture wastewater treatment in aquaponic system. J. Adv. Biol. 2015, 6, 1072-1078.

51. Wahyuningsih, S.; Effendi, H.; Wardiatno, Y. Nitrogen removal of aquaculture wastewater in aquaponic recirculation system. AACL Bioflux 2015, 8, 491-499.

52. Li, G.; Tao, L.; Li, X.-L.; Peng, L.; Song, C.-F.; Dai, L.-L.; Wu, Y.-Z.; Xie, L. Design and performance of a novel rice hydroponic biofilter in a pond-scale aquaponic recirculating system. Ecol. Eng. 2018, 125, 1-10. [CrossRef]

53. Yang, T. Production and Nutrition Recovery of Crops in a Recirculating Aquaponics System; Department of Horticulture, Purdue University: West Lafayette, IN, USA, 2019; p. 177.

54. Kim, H.J.; Yang, T. Characterizing nutrient composition and accumulation in tomato-, basil-, and lettuce-based aquaponic and hydroponic systems. Sci. Hortic. 2020. under review.

55. Su, Y.-M.; Lin, Y.-F.; Jing, S.-R.; Hou, P.-C.L. Plant growth and the performance of mangrove wetland microcosms for mariculture effluent depuration. Mar. Pollut. Bull. 2011, 62, 1455-1463. [CrossRef] [PubMed]

56. Hussain, T.; Verma, A.K.; Tiwari, V.K.; Prakash, C.; Rathore, G.; Shete, A.P.; Saharan, N. Effect of water flow rates on growth of Cyprinus carpio var. koi (Cyprinus carpio L., 1758) and spinach plant in aquaponic system. Aquac. Int. 2015, 23, 369-384. [CrossRef]

57. Endut, A.; Jusoh, A.; Ali, N.; Nik, W.W.; Hassan, A. A study on the optimal hydraulic loading rate and plant ratios in recirculation aquaponic system. Bioresour. Technol. 2010, 101, 1511-1517. [CrossRef] [PubMed]

58. Drew, M.C.; Saker, L.R. Nutrient supply and growth of seminal root system in barley. 2. Localized, compensatory increases in lateral root growth and rates of nitrate uptake when nitrate supply is restricted to only part of root system. J. Exp. Bot. 1975, 26, 79-90. [CrossRef]

59. Lambers, H.; Simpson, R.J.; Beilharz, V.C.; Dalling, M.J. Translocation and utilization of carbon in wheat (Triticum aestivum). Physiol. Plant. 1982, 56, 18-22. [CrossRef]

60. Wetzel, R.G. Microcommunities and microgradients: Linking nutrient regeneration, microbial mutualism, and high sustained aquatic primary production. Aquat. Ecol. 1993, 27, 3-9. [CrossRef]

61. Warwick, J.; Hill, A.R. Nitrate depletion in the riparian zone of a small woodland stream. Hydrobiologia 1988, 157, 231-240. [CrossRef]

62. Yildiz, H.Y.; Robaina, L.; Pirhonen, J.; Mente, E.; Domínguez, D.; Parisi, G. Fish Welfare in Aquaponic Systems: Its Relation to Water Quality with an Emphasis on Feed and Faeces-A Review. Water 2017, 9, 13. [CrossRef]

63. Lewis, W.M.; Yopp, J.H.; Schramm, H.L.; Brandenburg, A.M.; William, M. Lewis Fisheries Research Laboratory and Departments of Zoology and Botany Southern Illinois University Carbondale Illinois USA Use of Hydroponics to Maintain Quality of Recirculated Water in a Fish Culture System. Trans. Am. Fish. Soc. 1978, 107, 92-99. [CrossRef]

64. Quagrainie, K.K.; Flores, R.M.V.; Kim, H.J.; McClain, V. Economic analysis of aquaponics and hydroponics production in the US Midwest. J. Appl. Aquac. 2018, 30, 1-14. [CrossRef]

65. Buzby, K.M.; Waterland, N.L.; Semmens, K.J.; Lin, L.-S. Evaluating aquaponic crops in a freshwater flow-through fish culture system. Aquaculture 2016, 460, 15-24. [CrossRef]

66. Diem, T.N.T.; Konnerup, D.; Brix, H. Effects of recirculation rates on water quality and Oreochromis niloticus growth in aquaponic systems. Aquac. Eng. 2017, 78, 95-104. [CrossRef]

67. Khater, E.-S.G.; Bahnasawy, A.H.; Shams, A.E.-H.S.; Hassaan, M.S.; Hassan, Y.A. Utilization of effluent fish farms in tomato cultivation. Ecol. Eng. 2015, 83, 199-207. [CrossRef]

68. Delaide, B.; Delhaye, G.; Dermience, M.; Gott, J.; Soyeurt, H.; Jijakli, M.H. Plant and fish production performance, nutrient mass balances, energy and water use of the PAFF Box, a small-scale aquaponic system. Aquac. Eng. 2017, 78, 130-139. [CrossRef]

69. Love, D.C.; Uhl, M.S.; Genello, L. Energy and water use of a small-scale raft aquaponics system in Baltimore, Maryland, United States. Aquac. Eng. 2015, 68, 19-27. [CrossRef]

70. Lambers, H.; Poorter, H. Inherent Variation in Growth Rate between Higher Plants: A Search for Physiological Causes and Ecological Consequences. Adv. Ecol. Res. 1992, 23, 187-261.

71. Dijkstra, P.; Lambers, H. Analysis of specific leaf-area and photosynthesis of 2 inbred lines of plantago-major differing in relative growth-rate. New Phytol. 1989, 113, 283-290. [CrossRef] 
72. Poorter, H.; Bergkotte, M. Chemical composition of 24 wild species differing in relative growth rate. Plant Cell Environ. 1992, 15, 221-229. [CrossRef]

73. Caloin, M.; Yu, O. Analysis of the Time Course of Change in Nitrogen Content in Dactylis glomerata L. Using a Model of Plant Growth. Ann. Bot. 1984, 54, 69-76. [CrossRef]

74. Justes, E.; Mary, B.; Meynard, J.-M.; Machet, J.-M.; Thelier-Huche, L. Determination of a Critical Nitrogen Dilution Curve for Winter Wheat Crops. Ann. Bot. 1994, 74, 397-407. [CrossRef]

75. Marino, M.A.; Mazzanti, A.; Assuero, S.G.; Gastal, F.; Echeverria, H.E.; Andrade, F. Nitrogen Dilution Curves and Nitrogen Use Efficiency during Winter-Spring Growth of Annual Ryegrass. Agron. J. 2004, 96, 601-607. [CrossRef]

(C) 2020 by the authors. Licensee MDPI, Basel, Switzerland. This article is an open access article distributed under the terms and conditions of the Creative Commons Attribution (CC BY) license (http://creativecommons.org/licenses/by/4.0/). 